\title{
Las cofradías novohispanas de Tzintzuntzan. Bienes, prácticas y espacios de devoción
}

\author{
The Confraternities of Tzintzuntzan in New Spain, Properties \\ and Spaces of Devotion \\ José Manuel Martínez Aguilar \\ UNIVERSIDAD MICHOACANA DE SAN NICOLÁS DE HIDALGO, majmanuel999@hotmail.com
}

En este trabajo se explica cómo las cofradías fundadas en Tzintzuntzan durante la época virreinal tuvieron un rol importante en la consolidación de la religión católica, la participación social para fines comunes, el auxilio a los necesitados y la realización de fiestas patronales. Los ingresos de éstas, a través de las aportaciones de sus miembros y de las ganancias que generaba el manejo de bienes comunales, como tierras y ganado, permitieron solventar también parte de los gastos parroquiales, construir o reconstruir sus propias capillas y adquirir objetos y ornamentos costosos, a pesar de que a los visitadores episcopales les informaban no ser solventes. El estudio de las cofradías en este pueblo de la región lacustre de Michoacán da nueva luz para entender su historia social y simbólica en la época colonial. Está basado en fuentes documentales primarias que se cruzaron con estudios especializados y crónicas franciscanas.

Palabras Clave: hospital de indios, cofradías, capillas, Tercera orden, Santo Entierro, prácticas religiosas.

This paper explains how the confraternities founded in Tzintzuntzan during the colonial era played an important role in consolidating the Catholic religion, in fostering social participation for common ends, in assisting the needy, and in organizing festivities. The income that the confraternities generated through contributions by their members and the profits from the administration of commonly-held properties, such as land and cattle, also allowed them to cover some parochial expenses, build or rebuild their own chapels, and acquire costly objects and ornaments, although episcopal visitors always heard that those religious organizations were insolvent. The study of the confraternities in this town of the lake region of Michoacán sheds new light on their social and symbolic history in colonial times. The study is based on primary documentary sources complemented by specialized studies and Franciscan chronicles.

KEYwORDs: Indian hospitals, confraternities, chapels, Third Order, Holy Burial, religious practices.

Fecha de recepción del artículo: 9 de diciembre de 2015 / Fecha de aprobación: 7 de junio de 2016 / Fecha de recepción de la versión final: 5 de julio de 2016 


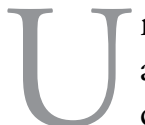
na vez levantada la capilla de Santa Ana de Tzintzuntzan, alrededor de 1526, ésta se convirtió en el centro de operaciones para la evangelización y difusión de la religión católica en toda la provincia franciscana de Michoacán, que llegó a convertirse, una década después, en la cabeza de la Custodia de San Pedro y San Pablo. Con el cambio de la sede provincial franciscana a Valladolid en 1565 y la supresión de su noviciado en 1622, el conjunto conventual de Tzintzuntzan fue perdiendo importancia, aunque conservó voz y voto en los capítulos de la orden y su estatus simbólico por haber sido el primero de la provincia. En su doctrina se mantuvo como el centro espacial y simbólico de las prácticas más importantes de la sociedad, pues, en éste se encontraba el templo parroquial, capillas, hospital de indios y el atrio donde se reunía el pueblo para ser parte de celebraciones, conmemoraciones religiosas y convivencia cotidiana.

A sólo cuatro años de que Tzintzuntzan obtuviera el reconocimiento como ciudad, Vasco de Quiroga tomó posesión como obispo de Michoacán en el mismo lugar, en 1538, para mudar poco tiempo después la sede catedralicia y la capital política a Pátzcuaro. Esta decisión dividió a la población tzintzuntzeña. Muchos de los españoles y numerosas familias de indios siguieron al obispo, mientras que otro grupo de indios, apoyados por algunos de los franciscanos y las autoridades locales, lucharon por mantener las exenciones y prerrogativas de la ciudad, y lograron que se les restituyera el título de ciudad y escudo de armas a finales del siglo xvi.

Aun con los beneficios que representaba el título, las constantes epidemias, las migraciones y las cargas de impuestos dejaron a la ciudad en un estado de pobreza como nunca desde las primeras décadas del siglo Xvir. Para entonces, la cofradía de la Inmaculada Concepción se mantuvo firme y fue esencial para atender solidariamente a los enfermos y más necesitados. En el mismo siglo y el siguiente se fundaron otras cofradías de indios y de españoles. Algunas fueron efímeras, pero otras se mantuvieron por décadas y fueron fundamentales para el sostenimiento del cura doctrinero, la conservación de las prácticas religiosas y la realización de obras materiales. ${ }^{1}$

${ }^{1}$ José Manuel Martínez Aguilar, "El conjunto conventual de San Francisco Tzint- 
En este trabajo se hará un acercamiento a la manera como se conformaron y funcionaron las cofradías de Tzintzuntzan durante la época virreinal, a las practicas que realizaban estos grupos, a los espacios físicos que fueron construidos para venerar a sus imágenes y llevar a cabo tales prácticas, así como a la declaración de sus bienes, ornamentos y alhajas de las capillas que eran administradas por los miembros de las cofradías. Todo con la finalidad de tener elementos para comprender, al menos de manera superficial, el papel que tuvieron estas agrupaciones en el desarrollo histórico de la ciudad lacustre, la configuración de espacios y edificios religiosos y sus prácticas socioculturales. Para cumplir con el objetivo se recurrió a revisar y analizar documentos inéditos y fuentes bibliográficas relacionadas con el tema de interés, que fueron confrontados con los vestigios materiales y espaciales del conjunto conventual de San Francisco de Tzintzuntzan.

El estudio se plantea desde la perspectiva de la historia social y cultural y la historia de la arquitectura. Toma la postura de Burke, quien menciona la interacción entre la gente y los edificios como una relación de doble dirección entre la cultura material de una parte y las prácticas sociales. De acuerdo con esta idea, los individuos y los grupos deciden cómo usar los espacios y los objetos para sus propios propósitos, pero estos propósitos pueden ser influenciados por formas heredadas y por la misma arquitectura. ${ }^{2}$

Para el análisis de los objetos de estudio se organizó el trabajo en tres partes. Primero se aborda el análisis de las cofradías de la Inmaculada Concepción en la Nueva España como marco de referencia. El segundo apartado aborda el caso del complejo hospitalario de la Concepción de Tzintzuntzan y la cofradía de la Inmaculada Concepción del mismo lugar. El último apartado se refiere a las cofradías no hospitalarias de la ciudad de estudio, éstas separadas por un subíndice.

zuntzan en la época virreinal, 1525-1766" (Tesis de doctorado en Historia, Instituto de Investigaciones Históricas, UMSNH, 2015).

${ }^{2}$ Peter Burke, "La historia social y cultural de la casa", Historia Critica (39) (septiembre-diciembre, 2009): 11-19. 


\section{Las COFRAdías de la InMaCulada Concepción en la Nueva España}

Las cofradías de la Nueva España eran asociaciones laicas católicas, cuyo principal fin consistía en llevar a cabo obras piadosas y de caridad entre sus semejantes, por lo que eran vistas por las autoridades religiosas como un instrumento ideal para consolidar la fe cristiana. Con la idea de que éstas representaban además un beneficio para el mejoramiento de las relaciones entre los feligreses y con el sacerdote, contribuían con el sostenimiento de las parroquias y con la obtención de fondos para complementar los ingresos de los curas, por medio del financiamiento de las misas y pago de servicios, desde el siglo XVI se comenzaron a fundar éstas en toda la Nueva España, llegan a ser numerosas para la segunda mitad del Xviı y todo el siglo XVIII. ${ }^{3}$ Entre sus actividades se encontraban las oraciones comunitarias para rogar por la salud de las personas o por la salvación de sus almas; la preparación y realización de procesiones; atención de los enfermos (principalmente las relacionadas con los hospitales de indios); financiamiento de gastos fúnebres de sus cofrades; así como el cuidado y mantenimiento de la Iglesia. ${ }^{4}$ Por los beneficios que representaban estos grupos, los párrocos y doctrineros de cada poblado promovieron su formación y supervisaron sus finanzas, aunque en un principio a los obispos les correspondía aprobar la fundación de dichas agrupaciones y sus estatutos. En el año 1600 se determinó que en la Nueva España y en el resto de las Indias españolas, las cofradías en formación debían solicitar permiso al rey, dando cuenta del propósito al que se destinaría la corporación, las constituciones por cumplir y los bienes que poseían, pero en la práctica no siempre se cumplían estas disposiciones. A finales del siglo XVIII, otra cédula del rey determinó que los ministros reales debían asistir a las juntas de cualquier cofradía, hermandad o congregación que se intentaran fundar o estuvieran erigidas. Cuando era nueva erección, los jueces

${ }^{3}$ Dagmar Bechtloff, Las cofradías en Michoacán durante la época de la Colonia. La religión y su relación política y económica en una sociedad intercultural (Zinacantepec: El Colegio de Michoacán, El Colegio Mexiquense, 1996), 21.

${ }^{4}$ Ibid., 65. 
eclesiásticos de sus respectivos distritos, que podían ser los curas párrocos, eran los encargados de disponer los estatutos. ${ }^{5}$

En el caso de Michoacán, las cofradías hospitalarias dedicadas a la Inmaculada Virgen de la Concepción se empezaron a fundar desde la primera mitad del siglo xvi a la par de los hospitales de indios, con una tarea primordial de atender a los numerosos indígenas aquejados por las constantes epidemias que surgieron desde los primeros ańos después del contacto con los europeos. El alarmante descenso de la población, a causa de las enfermedades a las que los nativos americanos no tenían inmunidad, motivó la construcción de hospitales en Michoacán, donde era primordial que se les atendiera y alimentara.

Si bien, las cofradías hospitalarias fueron fundamentales para el auxilio de los necesitados y enfermos, tenían también otras funciones como el adoctrinamiento de adultos; la administración de bienes para el sostenimiento del hospital; las fiestas religiosas; parte de los gastos de la parroquia y sus capillas; la preservación de las creencias religiosas. La participación del pueblo con cargos en las cofradías de la Inmaculada Concepción fomentaba la participación comunal y reafirmaba el estatus social de sus miembros, pues, para ocupar un cargo, los candidatos debían ser solventes y tener una reconocida reputación en la comunidad. Muchas habían obtenido la autorización real para su fundación y derechos de tierras, ganado o actividades económicas comunes que servían para sufragar sus gastos. Otras se mantenían únicamente de las contribuciones mensuales de los cofrades, llamadas cornadillo, y de las donaciones o limosnas de la comunidad. ${ }^{6}$

${ }^{5}$ Cofradias. Declarando que no se puede hacer junta alguna preparatoria ni con otro designio por los individuos de las cofradias hermandades, o congregaciones que se intenten fundar o estén erigidas en ellos sin que sean presididas por un ministro real. Madrid, 8 de marzo de 1791, AGN, Instituciones Coloniales, Gobierno Virreinal, Reales Cédulas Originales y Duplicados (100), Reales Cédulas Originales, vol. 148, exp. 165.

${ }^{6}$ Bechtloff, Las cofradias en Michoacán, 19. Dice Ricard que, con ello, los religiosos intentaban inculcar en los indígenas la previsión, la solidaridad, la necesidad del sacrificio individual en bien de la comunidad para cimentar, poco a poco, el espíritu de fraternidad. Robert Ricard, La conquista espiritual de México (México: Fondo de Cultura Económica, 1992), 24. 
Figura i. A la izquierda, capilla abierta de la Inmaculada Concepción. Al fondo, capilla de Nuestra Señora de la Soledad

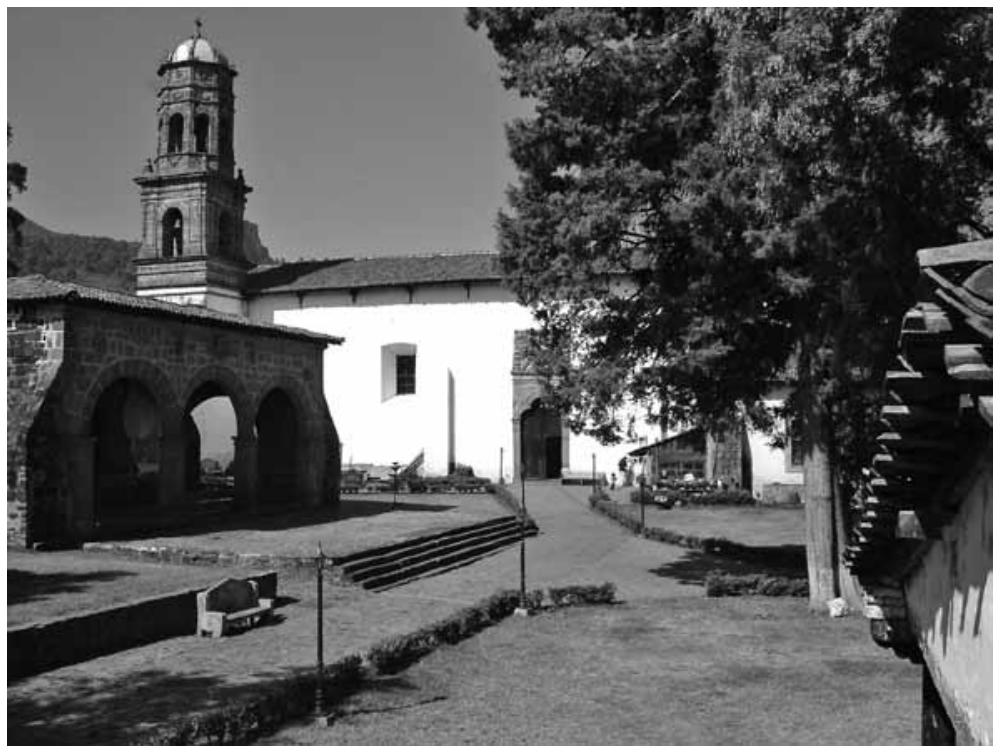

Fotografía del autor, julio de 2006.

Los dos personajes a quienes más se les ha atribuido la gloria de haber fundado hospitales en Michoacán son don Vasco de Quiroga y fray Juan de San Miguel. Del primero se conoce con certeza que fundó el de Santa Fe de México y Santa Fe de la Laguna, Michoacán, así como el de Santa Marta en Pátzcuaro; mientras que a fray Juan de San Miguel se le atribuyen una decena por todo Michoacán. ${ }^{7}$ Aparte de estos dos personajes, muchos otros religiosos agustinos y franciscanos fundaron hospitales y cofradías hospitalarias en la provincia michoacana, de los cuales quedan pocos vestigios materiales, pero sí reminiscencia de la participación comunitaria en la

${ }^{7}$ Fr. Alonso de La Rea, Crónica de la orden de Nuestro Seráfico Padre San Francisco Provincia de San Pedro y San Pablo de Michoacán en la Nueva España, libro I (México: La Voz de México, 1982), 324. Isidro Félix de Espinosa, Crónica de la provincia franciscana de los santos apóstoles San Pedro y San Pablo de Michoacán, apuntamientos bibliográficos de Nicolás León (Morelia: Instituto de Investigaciones Históricas, UMSNH, Morevallado, 2003), 125. 
práctica de diversas actividades religiosas y sociales que recuerdan estas corporaciones.

\section{El complejo hospitalario de la Concepción}

Los complejos hospitalarios, normalmente llamados hospitales, eran conjuntos de edificios y espacios abiertos que sirvieron para dar abrigo y cuidado a los indios enfermos; para acoger y albergar a los viajeros y gente de paso; el lugar de reunión para priostes y mayordomos, conocido como kenguería, ahí los indios hacían una especie de retiro espiritual; donde los miembros de los pueblos indígenas preparados en los conventos educaban y adiestraban a sus vecinos en la religión cristiana, la lectura, la escritura, música y latín. ${ }^{8}$

En cuanto a los espacios que comprendían estos complejos, se entiende con base en las Ordenanzas de Quiroga, eran lugares que contaban con una sala grande para enfermos contagiosos y enfrente de ella otra para los que tenían enfermedades no contagiosas; ambas contaban con su propia enfermería; en medio de las dos salas había uno o dos patios con una capilla abierta donde se oficiaban misas que podían escuchar los enfermos. Otros espacios estaban destinados al alojamiento del mayordomo y despensero, para oficinas y para la preparación y consumo de alimentos. ${ }^{9}$ Los espacios donde dormían los peregrinos eran salas grandes, probablemente sin muebles, donde los viajeros podían tender un petate para acostarse y cobijarse con mantas de algodón o sarapes que se les proporcionaban o que traían consigo. En el caso particular de Tzintzuntzan, los enfermos dormían de la misma manera cuando las cuentas del hospital no eran bien administradas, pues, a veces se utilizaba el dinero en fiestas en lugar de hacerlo en camas, frazadas y almohadas, como lo hizo ver el obispo de Michoacán, don Francisco de Aguilar y Seijas y Ulloa, cuando visitó la ciudad en 1679:

${ }^{8}$ Benedict Warren, Michoacán en la década de 1580 (Morelia, Instituto de Investigaciones Históricas, UMSNH, 2000), 77.

${ }^{9}$ Vasco de Quiroga, Reglas y ordenanzas para el Gobierno de los Hospitales de Santa Fe de México y Michoacán, Dispuestas por su fundador el Rmo. YVenerable Don Vasco de Quiroga, Primer Obispo de Michoacán (México: s. e., 1940). 
visitó así el libro del recibo y gasto del hospital de esta ciudad y como los autos y cuentas que han dado los priostes desde la última visita a ésta y parece por lo proveído que los susodichos no distribuyen los bienes, ni los gastan como deberían en el servicio y culto divino, cuidado y asistencia de los enfermos, y teniendo de renta bastantes para tenerle muy bien proveído de camas frazadas y almohadas para los pobres que en él se curaren, no tiene nada, consumiendo todos los bienes del dicho hospital en sus menesteres. $^{10}$

En Tzintzuntzan quedan pocos vestigios de los espacios que servían para la atención de los enfermos, pero su capilla abierta de la Concepción aún está de pie. Cuenta también con un atrio diferente al del conjunto conventual, que era usado casi exclusivamente por los indios. Al centro del patio se ubicaba una cruz y una pila sumergida para la imposición del bautismo por inmersión, única en su tipo; al extremo oriente, un campanario exento, típico de los edificios religiosos coloniales en Michoacán. La capilla de la Concepción debió ser levantada a mediados del siglo xvi y reconstruida en 1619 como lo revela una fecha grabada al frente de la misma. Para 1766 se describe de la siguiente manera:

la fábrica material consta de treinta varas de largo y quince de ancho, del presbiterio a la mitad es de pie con tres arcos muy bien hechos en el medio, y hasta puerta es de adobes, ésta tiene su arco de piedra, las puertas son de madera de cojín, cinco varas de alto y tres de ancho, tratables con su llave y una aldaba de fierro, con su coro correspondiente de madera sobre dos pilares de lo mismo, enrejado y nuevo, con vigas nuevas, tejado de tejamanil. Dentro de un arco hay un artesón de madera bien pintado, como también el arco y en el medio tiene una Señora de Concepción de bulto de tres cuartas dentro del cual se contiene el altar mayor de dicho hospital. ${ }^{11}$

${ }^{10}$ Aнсмо, Visitas, Asientos, 1679, caja 57, exp. 13, f. 107-109.

${ }^{11}$ También describe el altar mayor y los altares, las imágenes; posteriormente está el inventario de la plata y las alhajas de oro y plata. Diligencias ejecutadas sobre la entrega de la doctrina y jurisdicción de Tzintzuntzan. Tzintzuntzan, 25 de noviembre de 1766, АНСмо, Religiosos, Franciscanos, caja 275, exp. 142, 136, fs. 1766. 
La descripción deja ver que la capilla abierta había sido ampliada y cerrada con muros de adobe y un frontis de piedra con un arco. ${ }^{12}$ Por otro lado, la construcción para la curación de enfermos, conocida como "semanería" ya estaba en ruinas en 1789, como lo declaró el bachiller Gerónimo Sandi.

La capilla del hospital es menos aseada y capaz, las ruinas a ella vecinas, manifiestan hubo en otro tiempo formales enfermerías, y demás piezas conducentes a la curación de los enfermos, de las que hoy sólo queda una ruin casa con nombre de Semanería. ${ }^{13}$

Un año después, otro informe, describe el altar y las imágenes que se encontraban en la capilla del hospital, de la siguiente manera:

El altar mayor es de dos cuerpos, de siete varas de alto y cinco varas de ancho, con su remate pequeño; tiene cuatro columnas muy bien traídas y en medio del primer cuerpo, un nicho, donde está una imagen de Nuestra Señora de la Concepción, muy bella de vara y media de alto; su ropaje muy bueno de la misma madera, que llaman estofado; dentro de una vidriera está esta imagen que es de dos varas de alto y tres cuartas de ancho; resguárdala una cortina de raso morado, con sus orillas encarnadas, correspondiente al tamańo del nicho; a los lados tiene dos lienzos, uno de la Purísima Concepción y otro del señor San José, ambos de vara y media de largo y tres cuartas de ancho. En el segundo cuerpo hay tres lienzos; los de los lados de vara y media de largo y tres cuartas de ancho; el uno de Santa Teresa y el otro del doctor San Buenaventura; en el medio un lienzo de la Santísima Trinidad de vara y media en cuadro; en el remate del primer

${ }^{12}$ Esta parte agregada estuvo en uso hasta 1944 cuando fue retirada, quizás porque se consideró que no era un elemento original, así que fue colocado como una de las entradas del conjunto conventual; a unos 50 metros al norte de la misma capilla. Llama la atención que en la parte superior aún se conserva el relieve en piedra del escudo de Castilla y León, del siglo XviII.

${ }^{13}$ AGN, Historia, (73) exp. 6, fs. 131-239. José Bravo Ugarte, Inspección ocular de Michoacán. Para 1860 también se indica que el hospital se encontraba "casi arruinado". Romero J. Guadalupe, Michoacán y Guanajuato en 1860, noticias para formar la historia y la estadistica del Obispado, estudio preliminar de Agustín García (Morelia: Fimax publicistas, 1972), 280. 
cuerpo está el Nińo Jesús, de bulto, de tres cuartas de alto, vestido de una túnica blanca. Hay una cruz de madera en el altar, embutida de concha, de una tercia de alto, con su peanita; todo el referido altar muy bien dorado y nuevo [...] La sacristía de paredes de piedra, pequeńa, con vigas y tablas, cubierta de tejamanil, dentro de la cual no hay nada. ${ }^{14}$

En la misma capilla se encontraban las imágenes de san Roque, san Francisco y Nuestra Señora de la Concepción con un niño en brazos, que las guananchas sacaban los sábados por el atrio del conjunto conventual y las principales calles de la ciudad. ${ }^{15}$

Si bien, las actividades de socorro a enfermos, enseńanza y otras, que se habían realizado en el pasado ya no se efectuaban a finales del siglo XVIII, en uno de los espacios del complejo hospitalario conocido como kenguería se seguían reuniendo los cofrades de la Concepción para hacer elección de cargos y organizar las fiestas y conmemoraciones de la ciudad; los kengues o mayordomos se mudaban a este lugar durante un año, tiempo que duraba su cargo; ahí también se resguardaba el dinero y los documentos más importantes de la cofradía. En otros pueblos en la capilla del hospital se llevaban a cabo las reuniones de los cofrades, se desarrollaban sus actos de devoción y elegían sus autoridades. También podía ser el sitio de reunión de los cabildos y donde se guardaban los fondos comunes y los títulos del pueblo en una caja de dos o tres llaves. Dice Felipe Castro que era un espacio ritual, social y gubernativo, donde la comunidad decidía sus asuntos particulares sin mayor interferencia del párroco. ${ }^{16}$ En Tzintzuntzan no queda claro si la capilla de la Concepción cumplió las funciones de kenguería o se trataba de un edificio aparte. Según un visitante, en 1908:

Contigua al cementerio de la Parroquia, está una casa de adobe de construcción muy primitiva, la que se conoce por "La kenguería". Esta casa es

${ }^{14}$ Inventario del Hospital de la Ciudad de Tzintzuntzan, 18 de febrero de 1790, CEHM, fondo XXVIII, leg. 217, carp. 7, doc. 1, fojas 2.

${ }^{15}$ Las guananchas eran las mujeres encargadas del cuidado de la imagen de la Virgen del Hospital.

${ }^{16}$ Felipe Castro Gutiérrez, Los tarascos y el imperio español, 1600-1740 (México: UNAM, UMSNH, 2004), 292-293. 
la oficina de los mayordomos de los Santos y allí se reúnen al fin de cada año los ancianos y vecinos principales del pueblo para elegir los mayordomos que deben funcionar en el siguiente. ${ }^{17}$

\section{Cofradía de la Inmaculada Concepción}

Como en la mayoría de hospitales de la Nueva España, no se tiene conocimiento de la fecha de fundación del hospital de la Inmaculada Concepción de Tzintzuntzan ni de su cofradía, pero se puede pensar que fue poco después de la entrada de los primeros ministros evangélicos al lugar. Debió ser alguno de los primeros frailes franciscanos que residieron en Tzintzuntzan quien gestionó la instauración de un hospital en estas tierras, pues, aunque los nombres de casi todos los responsables de estas fundaciones hayan quedado en el anonimato, es bien sabido que desde el siglo Xvi los regulares fundaron numerosos hospitales, cofradías, hermandades y cajas de comunidad en la Nueva España. Es posible que haya sido fray Juan de San Miguel quien lo instauró alrededor de 1533, cuando se cree que estuvo en Tzintzuntzan, pero hasta ahora hay poca evidencia al respecto. También es probable que la fundación de este hospital y otros de Michoacán hayan sido promovidos o apoyados por Vasco de Quiroga cuando ya había tomado posesión del obispado. ${ }^{18}$

Sin saber la fecha exacta en que empezó a funcionar, ya se tiene registro de la existencia de tres hospitales en su doctrina: uno en la cabecera y dos en sus pueblos sujetos Ihuatzio y Cucuchucho. ${ }^{19} \mathrm{La}$ cofradía de su hospital, como las demás que se fundaron en la provincia bajo la advocación de la Inmaculada Concepción, tenía como fin principal socorrer a sus semejantes frente a las epidemias que asolaban a la población indígena, como ya se dijo, pero también la

${ }^{17}$ También habla del cambio de cargos que él atestiguó y de la veneración de Santa Elena. José M. de la Puente, "Tzintzuntzan, de mis notas de viajes”, Revista de la Sociedad Científica "Antonio Alzate" 27 (1 de junio de 1908): 418.

${ }^{18}$ Esta última probabilidad ya fue sugerida por Sara Sánchez. Benedict Warren y Sara Sánchez del Olmo, Las guatáperas (México: Rotodiseńo y Color, 2007).

${ }^{19}$ Alberto Carrillo Cázares, Michoacán en el otoño del siglo XVII (Zamora: El Colegio de Michoacán, Gobierno del Estado de Michoacán, 1993), 159-160. Dagmar Bechtloff, Las cofradias en Michoacán, 102. 
de hacer caridad y dar socorro a desamparados, huérfanos, viudas y ancianos; enseñar el catecismo, primeras letras y oficios para todos los niños y jóvenes. Los cargueros, es decir, quienes tomaban los cargos anuales en la cofradía, también tenían obligación de organizar las fiestas y conmemoraciones litúrgicas del pueblo, contribuir con los gastos diarios y reparaciones del hospital, templo y convento; incluso algunos de sus gastos estaban destinados a otro tipo de obras públicas, pues, existía una conexión muy fuerte entre la corporación hospitalaria y el gobierno civil, cuando trabajaban para fines comunes. ${ }^{20}$

Los cargos que se adquirían al ser miembro de la cofradía del hospital eran prioste, mayordomo, fiscal o escribano, diputados, madres y quengue o semanero. ${ }^{21}$ Los cargos adicionales eran sacristán, portero, vaquero, cantor y "ministril" o músico, encargado del coro, campanero, caballerango, muñidor, molendera y mitati o encardado del servicio doméstico inmediato al cura. ${ }^{22}$ Regularmente, los cargos de mayordomo, priostes, fiscales y el quengue, los ocupaban los indios miembros de los barrios principales, que generalmen-

${ }^{20}$ Algunos autores han expuesto la relación que había entre el cabildo, hospital y comunidad. Como ejemplo se tienen los documentos relacionados con unas tierras que el gobernador de Tzintzuntzan, Francisco de Pila, en 1597, compró a don Constantino Huitziméngari, por 450 pesos de oro común para el cabildo y hospital. Autos que sobre ciertas tierras sigue la república de indios de Tzintzuntzan contra los dueños de la hacienda la Tareta y la de Sanabria, AGN, Tierras, 3,448 (1), f. 7v-9. Delfina Esmeralda López Sarrelangue, La nobleza indígena de Pátzcuaro en la época virreinal (México: UNAM, Instituto de Investigaciones Históricas, 1965). María Teresa Sepúlveda y Herrera, Los cargos políticos y religiosos en la región del lago de Pátzcuaro, Colección científica, núm. 9 (México: INAH, 1974), 61 y 109. Louise M. Enkerlin Pauwels, "El cabildo indígena de Pátzcuaro: un espacio de poder en decadencia durante la primera mitad del siglo XvIII", en Autoridad y gobierno indigena en Michoacán, coord. Carlos S. Paredes Martínez y Marta Terán, 205 (México: El Colegio de Michoacán, CIESAS, INAH, UMSNH, 2003). Castro Gutiérrrez, Los tarascos, 291. Ángel Gutiérrez Equihua, "Los hospitales de la Sierra Tarasca en el siglo XviI" (Tesis de maestría en Arquitectura, Investigación y Restauración de Sitios y Monumentos, UMSNH, 2007).

${ }^{21}$ El de prioste era el cargo más importante porque representaba al hospital legalmente ante las autoridades civiles y eclesiásticas. Tenía la obligación de supervisar el funcionamiento del hospital, nombrar los cargos menores, y realizar un inventario de los gastos y recibos. El término semaneros viene de semana, era voluntario para auxiliar a los enfermos de los hospitales; la semanería era una especie de enfermería.

${ }^{22}$ Mahler Hernández Téllez, El convento de Nuestra Señora de la Asunción de Erongarícuaro 1547-1761 (Tesis de maestría en Historia, Instituto de Investigaciones Históricas, UMSNH, 2011), 118. Castro Gutiérrez, Los tarascos, 293-295. 
te pertenecían a las elites locales. ${ }^{23}$ Éstos tenían el compromiso de aportar recursos económicos propios para la organización de las fiestas del ańo cuando tenían el cargo, a cambio obtenían satisfacción moral, indultos en días especiales o prestigio social. No era raro que una misma persona tuviera un cargo en la cofradía del hospital y otro en el gobierno. Por otro lado, los puestos menores de diputados y madres eran adjudicados a vecinos de los barrios secundarios o indios del común. ${ }^{24}$

La fiesta principal de la cofradía del hospital era el primero de noviembre, día de la Purísima Concepción, durante la cual se reunían en el atrio del hospital los indios del pueblo a venerar a la Virgen con misas, música, comida y bebidas que eran ofrecidas por los cofrades o cargueros; así como jaripeos y tapadas de gallos en otra parte de la ciudad. También participaban en las conmemoraciones del Corpus Christi, Semana Santa, Pascua, Pentecostés, Navidad, fiesta de San Francisco $^{25}$ (4 de octubre), Santos Reyes (6 de enero), la Santa Cruz (3 de mayo), Carnaval, Santa Ana (26 de julio), San Antonio (13 de junio), San Pedro y San Pablo (29 de junio), San Nicolás (10 de septiembre), Todos los Santos (8 de diciembre), Nuestra Señora de la Soledad (18 de diciembre), y la del Señor del Rescate, ocho días antes del martes de Carnaval, que tuvo su origen a finales del siglo Xvir.

Desde el siglo Xvi, las procesiones del silencio, cantadas, de oración y flagelantes, eran comunes en distintas fechas durante el año, pero principalmente en la Semana Santa. Durante esta semana y todos los viernes de cuaresma los indios del hospital se disciplinaban durante una hora. A decir de Warren, esto hace pensar que los indios habían trasladado las prácticas de sangrías del paganismo a su cristianismo. ${ }^{26}$

${ }^{23}$ Laura Gemma Flores García y Carlos Paredes Martínez, "El cabildo, hospital y cofradías de indios en Pátzcuaro”, en Autoridad y gobierno indígena, 206.

${ }^{24}$ Castro Gutiérrez, Los tarascos, 287.

${ }^{25}$ En vísperas de esta fiesta se llevaba a cabo la confirmación de más de 500 personas de Tzintzuntzan y pueblos vecinos. AHCM, diocesano, sección gobierno, serie visitas, subserie asientos, 1679, caja 56, exp. 12, f. 7., Libro de confirmaciones y ordenes seńores Luna y Zeijas, 1670-1681.

${ }^{26}$ Benedict Warren, Vasco de Quiroga y sus Pueblos Hospitales de Santa Fe (México: Ediciones Hidalgo, UMSNH, 1997), 102. 
La cofradía de la Concepción además de cuidar la capilla, imágenes y objetos de la capilla del hospital y hacer donaciones y contribuciones en efectivo o en especie, administraba sus bienes como tierras agrícolas y ganado. Dichos hospitales lograron tener cierta autonomía del cura y la parroquia, como se lee en un informe de Tzintzuntzan, donde se señala la existencia de ganado en posesión de la Virgen, para su ornato, lustre y en general el de la iglesia: "pero como esto ocurre a cuenta de los indios jamás se consigue razón ni cuenta de sus productos". ${ }^{27} \mathrm{Al}$ respecto de sus bienes, un informe del siglo XvII asienta que en la ciudad de Tzintzuntzan hay hospital y tiene de sesenta a ochenta reses, vacas y bueyes, y siembran sementeras de maíz para el gasto del hospital. ${ }^{28}$ Entre 1624 y 1625 se comunica que la comunidad y hospital de Tzintzuntzan pagó 4 pesos por el registro de los hierros de su ganado, aunque no se especifica la cantidad de animales que poseían, como en el informe anterior. ${ }^{29}$ Los visitadores episcopales trataban de dar cuenta de sus bienes, pero lo único que podían hacer era revisar los libros de cuentas y confiar las declaraciones de los priostes encargados de dichos libros. En 1665, el padre Alonso de Soria visitó el hospital y lo encontró en buenas condiciones. Los libros de cuentas indicaban que tenía de recibo 2,021 pesos y de gasto una cantidad igual:

visitó así mismo el hospital de esta ciudad y lo halló muy decente capaz y adornado y con todas sus alhajas y bienes cabales, la enfermería conforme a lo mandado por su Sa Ylla y todo por la disposición y buen gobierno del dicho reverendo padre guardián a quien volvió a repetir muchas gracias

${ }^{27}$ Marta Terán, "Políticas contra las fiestas pueblerinas michoacanas durante la época borbónica”, en Historia y sociedad, ensayos del Seminario de Historia colonial de Michoacán, coord. Carlos S. Paredes Martínez, 368 (México: Instituto de Investigaciones Históricas, UMSNH, 1997).

${ }^{28}$ Ramón López Lara, El obispado de Michoacán en el siglo XVII (Morelia: Fimax, 1973), 181.

${ }^{29}$ Minuta de los hierros de la Provincia de Michoacán. Subtitulado como "Razón y minuta de los hierros que se han registrado en esta Provincia de Michoacán en virtud del mandamiento del Exmo. Sr. Conde de Gálvez virrey de esta Nueva Espańa y la cantidad que cada uno de los vecinos de esta Provincia dueños de los hierros y señales de ellos han pagado por la gracia y dentro de la media anata son los siguientes". BNAH, serie Michoacán, rollo 4 (115). 
[...] hizo parecer ante sí a don Pedro Vicente, prioste actual del dicho hospital de esta ciudad, para efecto de que diese cuentas del recibo y gasto de él y sus antecesores contenido desde que visitó el Yllmo Sr. Don Francisco Arnaldo de Yssasi, obispo de Puerto Rico, y exhibió un libro donde por él y sus partidos y ajustamientos de cuentas de los reverendos padres guardianes que han sido parece haber tenido de recibo dos mil y veinte y un pesos y de gasto otros, el vino acostumbrado y s P M R la oración lo dio adorar al pueblo y lo enseñó y entregó la llave al reverendo padre guardián dándole muchas gracias por el aseo curiosidad y limpieza con que estaba el dicho repositorio. ${ }^{30}$

Después de revisar la capilla del hospital, vasos, pila bautismal y una ara quebrada, recomendó que se tuviera una caja de tres llaves "donde entren los efecto de reales del dicho hospital que la una llave tenga el R. Pe. guardián y ministro de doctrina que es o fuere y la otra el prioste y la otra el mayordomo del dicho hospital". El prioste Pedro Vicente declaró estar en su poder y a su cargo doscientos y cuarenta pesos de maíz, doscientas y setenta y nueve reses y quince caballos.

En 1671, el obispo fray Francisco Sarmiento de Luna visitó Tzintzuntzan y encontró que el hospital había tenido desde la última visita de 1665, un mil cuatrocientos treinta y cuatro pesos de recibo y la misma cantidad de gasto. ${ }^{31}$ Sólo en ese año el hospital había tenido un gasto de novecientos noventa y seis pesos, mientras que había recibido seiscientos setenta y un pesos, por lo que el gasto había superado a lo recibido por trescientos veinticinco pesos. ${ }^{32}$ Viendo esta situación, el visitador recomendó que se tuviera mejor control de las cuentas y ordenó que no matara ni vendiera vaca alguna, ni disponer cosa alguna del hospital sin el aval del padre ministro, ${ }^{33}$ entre otras acciones, para

${ }^{30}$ Aнсмо, Visitas, Asientos, 1665, caja 56, exp. 9, fs. 53-57. Hacer una conversión de que representarían en la actualidad las cantidades de distintos momentos en la época virreinal es complejo y no es el objetivo de este trabajo.

${ }^{31}$ Ансмо, Visitas, Asientos, 1671, caja 57, exp. 13, fs. 79-81.

${ }^{32}$ Ibid., 13, fs. 107-109.

${ }^{33}$ El guardián era fray Sebastián de Fuica, quien después pasó al convento de Valladolid, con el mismo cargo. Tabla capitular provincial, Querétaro, 1676, АНсмо, Franciscanos, caja 17, exp. 48 , doc. 2 , f. 2. 
procurar el aumento del hospital y "redistribución en cosas esenciales de la Santa Iglesia de su hospital y para obras".

Un informe de 1681 nos muestra que el hospital tenía gran actividad en la atención de los enfermos. Dice que Tzintzuntzan

tiene un hospital en que está la enfermería, a que asiste número crecido de indios, por los barrios cada semana para el servicio de los enfermos que nunca faltan. Tiene dicho hospital seiscientas vacas de vientre, de cuyos esquilmos se pagan las misas de los difuntos que mueren de la ciudad; porque tiene obligación dicho hospital de cantar una misa por cualquier indio de dicha ciudad. ${ }^{34}$

Cuatro años después, el guardián de Tzintzuntzan, fray Gerónimo Sierra, ${ }^{35}$ informaba que en su doctrina había tres hospitales: "así mismo hago relación como en esta doctrina hay tres hospitales, los cuales tienen por finca unos chinchorros de vacas".

La siguiente información que se tiene es de 1791. Ésta se refiere nuevamente al hospital de Tzintzuntzan y su cofradía de la Concepción:

Tienen estos naturales cofradía de la Concepción, o del Hospital, con el mueble de veinte reses, que pastean en los bienes de la comunidad y que corre al cuidado de un prioste que eligen el que con las limosnas que colecta, lo que donan los cofrades y producto de las leches, paga de misa, sermón, sacristán, vísperas, procesión y cera, treinta y cuatro pesos de los cuales sólo recibe el cura dieciocho [...] los mayordomos que eligen los naturales para cada una de las festividades o funciones de la iglesia, costean de misas, sermones, cera, sacristía, etc., quinientos treinta y ocho pesos cuatro reales cada

\footnotetext{
${ }^{34}$ Aнсмо, Padrones, Asientos, 1681, caja 9, exp. 11, doc. 58, f. 4. Alberto Carrillo, Michoacán en el otoño, 459.

${ }^{35}$ Fray Gerónimo Sierra fue designado para tomar la doctrina de Tzintzuntzan el 6 de julio de 1683, donde estuvo por más de veinte años. AGN, Reales Cédulas Duplicadas, vol. D33, exp. 79. El 23 de octubre de 1703 renuncia a la doctrina de Tzintzuntzan. AHCMO, religiosos, franciscanos, XVIII, 0190, c. 269, leg. 69, exp. 2, f. 14. De 1699 a 1702 fue Provincial de la provincia franciscana de San Pedro y San Pablo de Michoacán. Isidro Félix de Espinosa, Crónica de la provincia franciscana, apéndice.
} 
año, pagando por separado los interesados y dolientes ocho pesos de un casamiento, cuatro pesos cuatro reales de un entierro de adulto, tres pesos del de un párvulo y nueve reales de un bautismo. ${ }^{36}$

Poco después, otro informe asienta que los fondos del hospital consisten en siete vacas de vientre, una yunta de bueyes y otras tres cabezas de tres ańos que se regulan en 49 pesos, pero como esto corre a cargo de los indios, jamás se recibe razón ni cuenta de sus productos ni su inversión. ${ }^{37}$ Un informe del bachiller Gerónimo Sandi de 1795 también deja ver la poca injerencia de los sacerdotes en las cuentas de las cofradías hospitalarias, con la siguiente declaración: "en los hospitales de esta cabecera, de Cocupao y de Ihuatzio se deja conocer que hubo algunos bienes de campo antiguamente, en el día de hoy el de esta ciudad tiene como unas diez cabezas de ganado mayor y esto se maneja inmediatamente por los gobernadores". ${ }^{38}$

En cuanto a los objetos destinados al culto, alhajas y ornamentos para la Virgen se puede ver en los informes que éstos eran costosos. Algunos debieron ser comprados con los recursos del hospital, pero otros eran donados por personas del pueblo como agradecimiento de favores recibidos o para ganar gracias. El inventario para la secularización del curato y doctrina registró que el hospital de Tzintzuntzan tenía a su cargo una corona, una cruz, una media luna, unos sarcillos de oro, un collar, una cruz de oro, dos pelícanos de oro, un rosario de coral, un relicario, siete anillos de oro, tres cintillos de oro, dos figuras de plata, una corona de plata, una lámpara, un frontal de madera, varios manteles, un atril, objetos de plata,

${ }^{36}$ Inspección ocular de Michoacán, AGN, Historia, (73) exp. 6, fs. 131-239. Publicado por José Bravo Ugarte, Inspección ocular de Michoacán, introducción y notas de José Bravo Ugarte (México: Jus, 1960), 36.

${ }^{37}$ David A. Brading y Óscar Mazín, eds., El gran Michoacán en 1791. Sociedad e ingreso eclesiástico en una diócesis novohispana (México: El Colegio de Michoacán, El Colegio de San Luis, 2009), 221.

${ }^{38}$ Informe presentado por el cura de Tzintzuntzan sobre su curato: pueblos que administra, distancias, capellanías, obras pias y número de feligreses. 4 de mayo de 1795, АНСмо, fondo Diocesano, sección Gobierno, serie informes, 0215, caja 511, exp. 109, f. 43. 
como ciriales, incensarios, platos, cálices, campanas, vasos, relicario, caja con chismera, custodia, coronas, diadema, palmas y diadema, cajita, ostiario, vara de San José, resplandor y tres chismeras, entre otros objetos. $^{39}$

\section{LAS COFRADÍAS NO HOSPITALARIAS}

Después de que se suprimió el noviciado de Tzintzuntzan en 1622, los frailes que habitaban el convento de la ciudad lacustre se dedicaron a administrar su doctrina, manteniéndose de las aportaciones de la propia comunidad y del salario que les hacía llegar la Corona. Fue entonces cuando las cofradías tomaron un rol más protagonista en el sostenimiento material del templo parroquial, convento, hospital y capillas, así como en la labor de mantener viva la devoción religiosa del pueblo, con la participación de sus miembros en obras de caridad y haciendo colectas para misas, procesiones, fiestas y conmemoraciones religiosas.

La cofradía de la Inmaculada Concepción era ya una organización antigua que seguía funcionando con regularidad. ${ }^{40}$ En el siguiente siglo se reunieron en una la de Nuestra Seńora de la Soledad y Ánimas del Purgatorio, así como la de San Nicolás, San Jerónimo y el Santo Nińo. Para el siglo xviII, se fundaron la del Santísimo Sacramento o Divinísimo y la de la Tercera Orden. ${ }^{41}$ Todas ellas se habían organizado con base en estamentos étnicos: por un lado, las de indígenas y, por otro, las de espańoles y criollos. En el caso de las cofradías de indios, probablemente como sucedía en Pátzcuaro, los indios "principales" pertenecientes a las antiguas familias de nobles indígenas eran quienes ocupaban los principales cargos, aunque

${ }^{39}$ Inventario de los bienes del Hospital. Tzintzuntzan, a 25 de noviembre de 1766, Ансмо, Religiosos, Franciscanos, caja 275, exp. 142, 136 f. 1,766.

${ }^{40}$ AGN, ramo Historia, 73 (6), f. 131-239. Dagmar Bechtloff, Las cofradías en Michoacán, 102.

${ }^{41}$ Según Bechtloff, en 1712 sólo se registraban las de la Purísima Concepción, la del Señor Divino y la del Santísimo Sacramento, pero en otros documentos del siglo Xviı ya se hace referencia a la de la Soledad, como se verá líneas abajo. Dagmar Bechtloff, Las cofradias en Michoacán, 102 y 291. 
cualquiera que tuviera espíritu de servicio y se ajustara a los estatutos de la cofradía podía incorporarse a ella. ${ }^{42}$

\section{Cofradia de Nuestra Señora de la Soledad y Ánimas del Purgatorio}

Se desconoce la fecha de la fundación de la cofradía de Nuestra Seńora de la Soledad de Tzintzuntzan, que bien pudo ser a principios del siglo XVII o incluso a finales del XVI, como una de las que apoyó fray Pedro de Pila. ${ }^{43}$ Lo que sí se sabe es que a mediados del siglo XVII ya existía una corporación con este nombre. ${ }^{44}$ Según información del obispo fray Francisco Sarmiento de Luna, ${ }^{45}$ quien visitó la cofradía de Nuestra Señora de la Soledad en 1671, "ésta fue fundada en la capilla del mismo nombre que está en esta ciudad". ${ }^{46}$ Otro documento que da testimonio de la visita de don Francisco de Aguilar a Tzintzuntzan en 1679 parece contradecir al anterior, pues declara que: "en esta iglesia parroquial [...] se visitó el libro del recibo y gasto que ha tenido la cofradía de Na. Sa. de la Soledad y Ánimas del purgatorio fundada en la dicha iglesia". ${ }^{47}$ Seguramente, la segunda afirmación es la correcta, pues, las cofradías no podían fundarse sino en una parroquia o en una capilla abierta, donde pudieran tener un altar asignado para sus misas y demás ceremonias. ${ }^{48}$

${ }^{42}$ Dagmar Bechtloff, "La formación de una sociedad intercultural: las cofradías en el Michoacán colonial”, en Historia Mexicana 43(2) (170) (octubre-diciembre 1993): 256. José Martín Torres Vega, "La incidencia de la orden dominica de mujeres en el espacio urbano-arquitectónico de Pátzcuaro y el obispado de Michoacán, 1747-1867" (Tesis de doctorado en Arquitectura, Universidad Autónoma de Aguascalientes, 2013), 42-46.

${ }^{43}$ José Manuel Martínez Aguilar, Fray Pedro de Pila. El protector de Tzintzuntzan (Editorial Académica Española, 2015). José Manuel Martínez Aguilar, "Fray Pedro de Pila y su obra en Tzintzuntzan”, Anuario de Historia de la Iglesia (24) (2015): 383-403.

${ }^{44}$ Carrillo Cázares, Michoacán en el otoño, 160.

${ }^{45}$ Religioso de la Orden de San Agustín. Obispo de Michoacán entre 1668 y 1674. Juan Carlos Ruiz Guadalajara, Documentos para la historia del obispado de Michoacán, tomo I (México: Frente de Afirmación Hispanista, Fundación Cultural "Dr. Enrique Arreguín Vélez", 1993), 107.

${ }_{46}^{4}$ Aнсмо, Visitas, Asientos, 1671, caja 57, exp. 13, fs. 79-81.

${ }^{47}$ Ibid., fs. 107-109.

${ }^{48}$ Bechtloff, Las cofradías en Michoacán, 50. Patricia Escandón, “Tancítaro y la tierra caliente bajo la administración franciscana, 1552-1636", Relaciones Estudios de Historia y Sociedad xxvi(103) (verano 2005): 252. 
En este último documento es la primera vez que se hace referencia a la cofradía de Nuestra Señora de la Soledad y Ánimas del Purgatorio. El segundo nombre pertenecía a una hermandad fundada en la iglesia parroquial, la cual en 1665 estaba adherida a la cofradía de San Nicolás, y posteriormente se fusionó con la de la Soledad. ${ }^{49}$ Después de esa amalgama, la misma cofradía a veces era referida como de Nuestra Señora de la Soledad y otras como de las Ánimas del Purgatorio. ${ }^{50}$

En el siglo Xvi, eran comunes las cofradías de las Ánimas en la Nueva España. Éstas tenían como uno de sus fines el orar por la salvación de las almas de sus difuntos y de sus miembros y familias para que el tiempo que pasaran en el purgatorio fuera menor. Además de las oraciones, realizaban una misa el último viernes de cada mes durante la Cuaresma y, en particular, la Semana Santa, hacían obras de beneficencia y las penitencias, generalmente, ejecutadas por medio de la flagelación. ${ }^{51}$ También sus miembros asumían los gastos del sacristán y cantores.

Phillips nos dice que los miembros de estas cofradías desfilaban por los claustros cantando responsos y siguiendo la procesión dirigida por los frailes..$^{52}$ En Tzintzuntzan, esta práctica no era exclusiva de los miembros de las Ánimas, pues, se sabe que la del Santo Entierro también participaba de ella, haciendo paradas en cada una de las esquinas del claustro, donde se encontraban sus imágenes más veneradas, como se verá abajo. Ambas agrupaciones tenían importante presencia, sobre todo, en las procesiones de la Semana Santa que se realizaban a media noche alrededor del atrio del conjunto conventual y por las principales calles.

En algunas de las fiestas principales, la gente del pueblo festejaba por días con corridas de toros, comida, bebida y música, que era financiada por las cofradías. El 25 de febrero de 1774, por ejemplo,

${ }^{49}$ Aнсмо, Visitas, Asientos, 1665, caja 56, exp. 9, fs. 53-57.

${ }^{50}$ Aнсмо, Mandatos, Provisiones Reales, 1685, caja 4, exp. 21, f. 76.

${ }^{51}$ H. Cecilia Sierra Paniagua, "La cofradía del pueblo del Señor de San Juan Pungarabato", en Relaciones Estudios de Historia y Sociedad xxxvi(144) (otońo 2015): 156.

${ }^{52}$ Richard E. Phillips, "La participación de los indígenas en las procesiones por los claustros del siglo xvi en México", Relaciones Estudios de Historia y Sociedad xx(78) (primavera 1999), 237. 
durante domingo de carnestolendas, en carnaval, el gobernador Antonio Basilio Flamenco de la Peńa se propuso limitar los gastos de la cofradía de la Soledad, impidiendo "la corruptela de un banquete que se ha acostumbrado hacer por el mayordomo y cofradía de Nuestra Señora de la Soledad, el domingo de carnestolendas". El objetivo, según el gobernador, era evitar la embriaguez, pero el mayordomo Miguel Cuiris no atendió a los designios de Flamenco y fue castigado con unos azotes. Sobre el asunto, el cura del lugar Manuel González de Anzo y el alcalde mayor Felipe Ordońez y Sarmiento no estaban de acuerdo con las atribuciones que se había tomado el gobernador sin la anuencia de las autoridades españolas. ${ }^{53}$

Después de haber tenido su centro de reunión en el templo parroquial, los cofrades de la Soledad construyeron una capilla propia que, como dijimos, existía en $1671 .^{54}$ Según George Foster, un tal "padre Leso" fue el encargado de la terminación de la misma en 1631, "cuya tumba es visible dentro del edificio". ${ }^{55}$ No da referencia de su fuente y la fecha puede ser correcta, pero no parece corresponder con el supuesto gestor de su construcción, pues, el padre Leso a quien se refiere debe ser el bachiller Manuel Nicolás de Leso (o Lezo), un clérigo que fue subdiácono de la catedral de Valladolid entre 1765 y 1786; criollo de nacimiento, oriundo de la ciudad de Tzintzuntzan, ordenado a título de la lengua purépecha y uno de los fundadores de la cofradía de terciaros en su ciudad natal. ${ }^{56}$ Según un

${ }^{53}$ AHMM, fondo Independiente, c-2 C, exp. 5, f. 1f.: Antonio Basilio Flamenco, gobernador de naturales de la ciudad de Zinzunzan ante el alcalde mayor Felipe Ordoñez y Sarmiento, sigue autos para impedir se lleve a cabo el banquete que se acostumbra ofrecer por la cofradia de Nuestra Señora de la Soledad el domingo de carnestolendas por la embriaguez que se ocasiona, 1774. Nicolás Paniagua Aguilar, "De la privilegiada y leal ciudad de indios al ayuntamiento constitucional de Tzintzuntzan, 1718-1826" (Tesis maestría en Historia, Instituto de Investigaciones Históricas, uMNSH, 2015), 132-133, 225-228.

${ }^{54}$ AHCM, fondo Diocesano, sección Gobierno, serie Visitas, subserie Asientos, 1671, caja 57 , exp. 13, f. 79-81.

${ }^{55}$ George M. Foster, Los hijos del imperio, la gente de Tzintzuntzan (Zamora: El Colegio de Michoacán, 2000). Casualmente la cofradía de las Benditas Ánimas de Pátzcuaro fue aprobada en 1631, pero tampoco se conoce su fundación. Dagmar Bechtloff, Las cofradias en Michoacán, 321.

${ }^{56}$ Óscar Mazín, El cabildo catedral de Valladolid de Michoacán (Zamora: El Colegio de Michoacán, 1996), 373. En 1786 fue acusado de no querer contribuir con 600 pesos que el deán y cabildo habían acordado para beneficio de los pobres de la ciudad y del obis- 
artículo de 1908, "la iglesia" (de la Soledad) con todos sus altares, imágenes y paramentos, fue costeada por el canónigo don Manuel Leso, de la Catedral de Morelia, quien fue originario de Tzintzuntzan". Agrega que en el presbiterio "sin caja ni cosa alguna que lo resguarde, reposan los restos del Canónigo D. Manuel Leso cuyo cráneo sorprende verdaderamente por sus deformes y colosales dimensiones". ${ }^{57}$ Esto hace suponer que el padre Leso que menciona Foster vivió en el siglo XVIII y no en el XVII.

Por otro lado, la capilla de Nuestra Señora de la Soledad que se menciona en 1671 era muy diferente y de menores dimensiones a las que tiene hoy día. ${ }^{58}$ La prueba nos la da la información emitida en los autos de secularización del conjunto conventual de Tzintzuntzan de 1766, al describir el inmueble de la siguiente manera:

Primeramente la capilla tiene treinta varas de largo y ocho de ancho con dos puertas, la una con llave y la otra sin ella. Y también tiene dicha capilla su artesón nuevo y su entarimado hasta la mitad del suelo. Y también hay un altar de un cuerpo, dorado con su remate, y cuatro columnas, decente. En el medio de él está una urna dorada con sus dos chapas y una llave que encierra dentro una bellísima imagen del Santo Entierro de Cristo. ${ }^{59}$

Si se revisan las medidas que nos proporciona el documento y las comparamos con el edificio actual, se podrá notar gran diferencia

pado, causando "el mayor horror, pesar y escándalo", según el obispo de Michoacán, AGN, Regio patronato indiano, Instituciones nacionales, caja 593, 30,942, exp. 13, f. 144.

${ }^{57}$ J. M. de la Puente, “Tzintzuntzan”, 418. Cofradía de la Tercera Orden de Tzintzuntzan, APT, libro $1^{\circ}$ de la cofradía de la Tercera Orden, f. 40.

${ }^{58}$ En un cuadro al óleo, del siglo xviII, que perteneció a la capilla de San Nicolás y que actualmente se encuentra en la sacristía del templo parroquial, se ve a san Francisco orando sobre una loma. Al fondo se aprecia el convento y templo de San Francisco, así como una pequeña construcción en el lugar donde ahora está la capilla de la Soledad. Una de las ilustraciones que presenta Beaumont en su Crónica muestra dos construcciones sencillas, como casas, donde actualmente está la capilla; quizá representando el hospital y la capilla primitiva. Pablo Beaumont, Crónica de Michoacán, 3 vols. (Morelia: Balsal, 1985).

${ }^{59}$ Secularización de la doctrina y curato de Tzintzuntzan, 1762-1767, АНСM, fondo Diocesano, sección Gobierno, serie Religiosos, subserie Franciscanos, caja 275, exp. 142, f. 130 . 
en sus dimensiones, pues, la nave que ahí se describe tenía 30 varas de largo por 8 de ancho, mientras que la actual tiene unas 56 varas de largo por 17 de ancho, es decir, una superficie de casi cuatro veces la original o mucho más si agrega la superficie de la sacristía y el espacio anexo al oriente de la torre. También podemos ver en esta descripción que el artesón era nuevo, lo que nos indica que tenía poco de haberse terminado de construir el inmueble. De hecho, cuatro años antes el gobernador, alcaldes, oficiales y común de la ciudad de Tzintzuntzan habían ofrecido que la capilla de la Soledad fuera erigida a parroquia; ${ }^{60}$ sin embargo, no fue aceptada tal petición, porque "La Soledad era una capilla antigua de los indios que no tenía las proporciones correspondientes para servir de iglesia parroquial". ${ }^{61}$

Referente a la nueva capilla, la historiadora del arte Esperanza Ramírez nos habla de un documento de 1806 en el cual una persona de nombre José Francisco Velasco juró haber construido un año atrás la capilla de la Soledad de Tzintzuntzan. Desgraciadamente, la referencia que ofrece Ramírez cambió y el documento no fue encontrado en su nueva clasificación. ${ }^{62} \mathrm{Si}$ el padre Leso construyó una capilla debió ser después de la secularización de 1766. Parece ser que el diácono aportó los recursos económicos y el señor Velasco se encargó de la ejecución de la obra. De cualquier manera, si la capilla que conocemos hoy se construyó en 1805 como lo revela una inscripción en el frontispicio del edificio, es casi seguro que haya iniciado algunos ańos antes, pues, dieciséis años atrás ya estaba al menos la nave completa y sólo se había colocado un retablo, como lo señala una información: "hay también una capilla de la Soledad de excesi-

${ }^{60}$ Firmado el de marzo de 1762. Secularización del curato y doctrina de Tzintzuntzan, 1762-1767, AGN, Patronato Indiano, Clero Regular y Secular (024), contenedor 47, vol. 119 , exp. 6.

${ }^{61}$ El obispo Sánchez de Tagle emite un dictamen sobre la secularización de Tzintzuntzan, Valladolid a 19 de septiembre de 1766, Secularización de la doctrina y curato de Tzintzuntzan, 1762-1767, АHCM, fondo Diocesano, sección Gobierno, serie Religiosos, subserie Franciscanos, caja 275, exp. 142, 136 fs.

${ }^{62}$ José Francisco Velasco presenta juramento de que construyó una capilla en Tzintzuntzan, Ансмо, Negocios diversos, leg. 5, 1806. Apud Esperanza Ramírez Romero, Catálogo de monumentos históricos de la Región Lacustre de Pátzcuaro, tomo II (Morelia: uMSNH, Gobierno del Estado de Michoacán, 1990), 436. 
va longitud, con un solo retablo dorado, cielo superior de tablas, mal pintado y paredes de adobe, distinguiéndose entre sus efigies la de Jesucristo acostado en una decente urna". ${ }^{63}$ Sin duda, el edificio completo se terminó tiempo después, como lo atestiguan dos leyendas en las paredes de la escalera que sube al campanario de la misma capilla. En una de las inscripciones dice: "Se hizo la edificación de este templo en el mes de marzo de 1811”. En la otra se lee: "Se blanqueó esta iglesia en el mes de julio de 1817”. Como era común en la mayoría de los templos, la torre era la última que se levantaba, así es que la nave del templo debió terminarse en 1805 y la torre hasta 1817.

Respecto a las cuentas de la cofradía de la Soledad en la segunda mitad del siglo XVII, éstas apenas alcanzaban para cubrir los gastos necesarios y en ocasiones el gasto excedía los ingresos, según lo informaron al padre fray Alonso de Soria a Tzintzuntzan en 1665:

Así mismo hizo parecer para el mismo efecto a Jhonas Sirahuato mayordomo actual de la cofradía de Ntra. Señora de la Soledad y a los demás que lo han sido y el dicho mayordomo exhibió un libro que por él y sus partidas pareciera haber tenido de recibo doscientos y cuarenta y dos pesos y de gasto en lo necesario trescientos pesos los que parece excede el gasto al recibo y cincuenta y ocho pesos los cuales les perdonaron a la dicha cofradía que vistas dichas cuentas por su $\mathrm{R}$ (reverendo) $\mathrm{M}$ (inistro) las aprobó y mandó al mayordomo y a los que adelante fueren, miren por la conservación y aumento de dicha cofradía. ${ }^{64}$

En posterior visita de fray Francisco Sarmiento de Luna a la misma ciudad en 1671 , los ingresos de la cofradía habían aumentado en $35 \%$, pero también los gastos se incrementaron en $38 \%$, respecto a los de 1665 , es decir, 88 pesos más de gasto que lo que tuvieron de ingreso.

Así mismo el libro de recibo y gasto de la cofradía de Nuestra Señora de la Soledad fundada en la capilla de este título que está en esta ciudad, el cual presentó ante su Sia Ilustrísima Juan de los Reyes, mayordomo actual, y por

${ }^{63}$ AGN, Historia, vol. 73. José Bravo Ugarte, Inspección ocular de Michoacán, 35.

${ }^{64}$ Aнсмо, Visitas, Asientos, 1665, caja 56, exp. 9, fs. 53-57. 
Figura 2. Vista de la capilla de Nuestra Señora de la Soledad

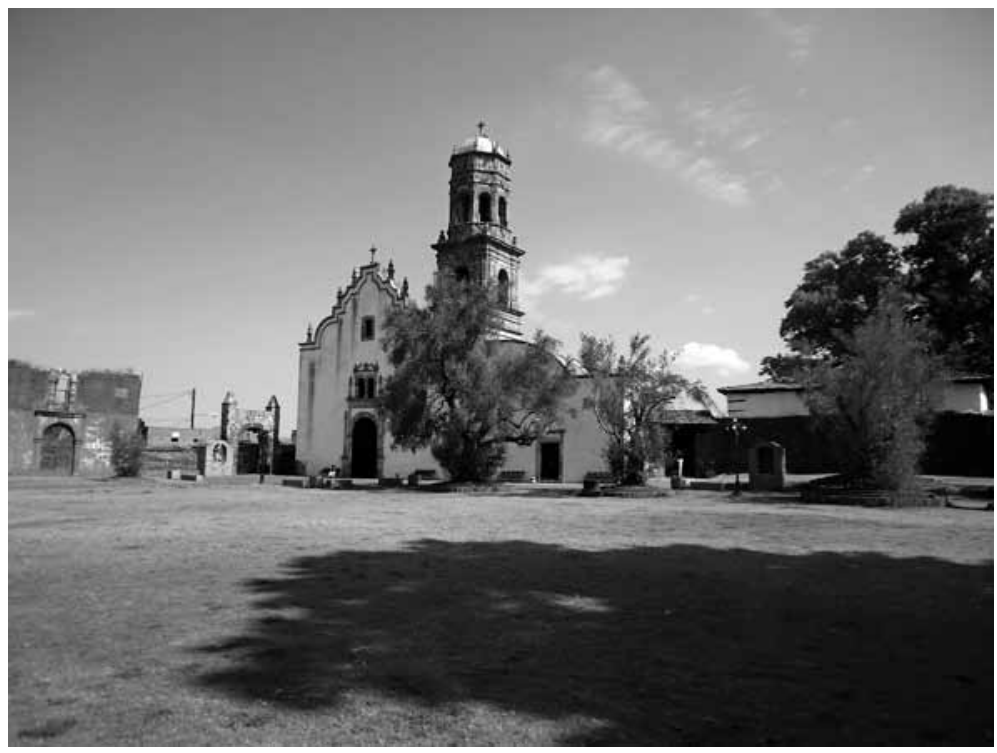

Fotografía tomada por el autor en diciembre de 2013.

dicho libro y sus cuentas contó que los mayordomos tenían de recibo trecientos y veintisiete pesos y de gasto cuatrocientos quince pesos y cinco reales con que alcanzó el gasto al recibo en ochenta y ocho pesos y cinco reales. ${ }^{65}$

Ocho años después, don Francisco de Aguilar solicitó el libro de cuentas de la cofradía de la Soledad y encontró que los gastos superaban 30 pesos a los ingresos.

Así mismo se visitó el libro del recibo y gasto que ha tenido la cofradía de Na. Sa. de la Soledad y Ánimas del Purgatorio, fundada en la dicha iglesia, y parece por autos y ajustes que en él se han hecho haber tenido de recibo trescientos y sesenta pesos y de gasto trescientos y noventa pesos con que

${ }^{65}$ AHCM, fondo Diocesano, sección Gobierno, serie Visitas, subserie Asientos, 1671, caja 57 , exp. 13, f. $79-81$. 
alcanzaron los mayordomos que han sido en treinta pesos que perdonaron y juraron las cuentas en forma y conforme a derecho. ${ }^{66}$

Para 1685, fray Gerónimo Sierra informó que había tres cofradías en la cabecera: "una de las Animas de purgatorio, otra de San Nicolás de Tolentino y otra del Sto. Entierro de Cristo, las cuales no tienen fincas y sólo se sustentan de las limosnas que dan los cofrades, pidiendo con un plato dentro de las canales de este pueblo". ${ }^{67}$

\section{Cofradia de San Nicolás de Tolentino}

La cofradía dedicada a San Nicolás Tolentino ya existía en 1665, integrada entonces con la hermandad de las Ánimas. Se vuelve a mencionar en 1671 y luego en 1685, como una de las tres cofradías de Tzintzuntzan, junto con la de las Ánimas y la del Santo Entierro. ${ }^{68}$

Es probable que esta cofradía se haya fundado en el templo parroquial, donde había un nicho con la imagen de San Nicolás "muy lindo". Posteriormente sus miembros buscaron un lugar donde reunirse y venerar al santo de su devoción. Con la aprobación del ministro religioso del lugar, resolvieron cerrar la capilla abierta del convento con muros de adobe y piedra, así como techo de madera y teja. El recinto medía unos $12 \mathrm{~m}$ de largo por $6.5 \mathrm{~m}$ de ancho. ${ }^{69}$

Si se pone atención en el mapa de Tzintzuntzan, que dio a conocer Beaumont, se puede apreciar que la capilla "abierta" del convento no está en el paño del muro del resto del convento y templo, sino saliente, con un pórtico de dos arcos. Una pintura de san Francisco, del siglo XVIII, que se encontraba en el interior de la misma capilla, nos confirma que ésta tenía un pórtico de tres arcos, similar al de la capilla del hospital. Esta capilla cerrada es descrita de la siguiente manera:

${ }^{66}$ AHCM, fondo Diocesano, sección Gobierno, serie Visitas, subserie Asientos, 1679, caja 56, exp. 12, f. 7.

${ }^{67}$ AHCM, Mandatos, Provisiones Reales, 1685, caja 4, exp. 21, f. 76.

${ }^{68}$ AHCM, Mandatos, Provisiones Reales, 1685, caja 4, exp. 21, f. 76.

${ }^{69}$ Secularización de la doctrina y curato de Tzintzuntzan, 1762-1767, АНСM, fondo Diocesano, sección Gobierno, serie Religiosos, subserie Franciscanos, caja 275, exp. 142, $136 \mathrm{fs}$. 
Y también una capilla de San Nicolás que está en el cementerio, su fábrica es de adobe de quince varas de largo y ocho de ancho, con vigas y techo de tejamanil, tiene dos imágenes de San Nicolás, una de vara y cuarta y otra de San Nicolás penitente; un crucifijo de vara y cuarta y unas andas del santo. ${ }^{70}$

$\mathrm{Al}$ interior de esta capilla se encontraba un lienzo del siglo XviII, que en la actualidad se resguarda en la sacristía: "un lienzo de nuestro padre San Francisco con el mapa de la ciudad antigua de Tzintzuntzan con tres bellos arcos al oriente y uno al norte donde está el púlpito de madera y donde se hace el Descendimiento". ${ }^{71}$ Información de finales del siglo XVıII señala que: "La capilla de San Nicolás es el último edificio de esta clase, con el de Nuestra Señora de Guadalupe, que está en uno de los extremos de la población, fabricadas igualmente de adobe y sin recomendable adorno interior. ${ }^{72}$

Por otro lado, revisando el acta constitutiva de la cofradía de San Nicolás de Chamacuero, inferimos que la de Tzintzuntzan con la misma advocación funcionaba de la siguiente manera: primero, era menester tener tres libros, uno para asentar los nombres de los miembros de la cofradía; otro para anotar las limosnas; y el último para llevar las cuentas de gasto y recibo. Se debían nombrar enfermeros y enfermeras para que acudieran a la curación de los enfermos cofrades y para la velación de quien falleciera; la cofradía en este caso pagaría los gastos del entierro y diría una misa cantada por el difunto. El viernes de cada semana se debería pedir limosna voluntaria entre los cofrades varones y mujeres. El segundo domingo de cada mes se cantaría una misa a todos los hermanos cofrades vivos o

70 “y al lado diestro una bóveda, donde está un lienzo de nuestro Padre San Francisco con el mapa de la ciudad antigua de Tzintzuntzan”. Secularización de la doctrina y curato de Tzintzuntzan, 1762-1767, АHCM, fondo Diocesano, sección Gobierno, serie Religiosos, subserie Franciscanos, caja 275, exp. 142, 136 fs. A principios del siglo XvIII se dice que la única cofradía que existía era la del Divinísimo. No se sabe si la de San Nicolás estaba extinta, temporalmente sin actividad, no fue considerada o no se informó al visitador de su existencia. Raro es que tampoco se mencione la Concepción. Brading y Mazín, eds., El gran Michoacán, 221.

${ }^{71}$ Idem. A principios del siglo xx los arcos se encontraban tapeados.

${ }^{72}$ AGN, Historia, vol. 73. Bravo Ugarte, Inspección ocular de Michoacán, 35, 36. 
difuntos, por la que se pagarían dos pesos al guardián del convento. El primer domingo después de la fiesta de San Nicolás (6 de octubre) ${ }^{73}$ se debía celebrar la fiesta con procesión, pompa y autoridad, pagando tres presos de limosna. El viernes antes del domingo de Ramos, tenían que sacar la procesión de sangre por las partes acostumbradas, hacer una misa cantada y un sermón, por lo que se debían pagar doce pesos. En el aniversario de los difuntos se ofrecería una misa cantada con su vigía y responso por los cofrades, aportando cinco pesos de limosna. Se determinaba pagar un real cada mes para sustentar la cofradía hasta que se tuviera finca propia. En la fiesta de San Nicolás se pagarían dos pesos y en la procesión de sangre un peso. En las doce misas del año, todos los cofrades llevarían a cabo una procesión por el claustro del convento, llevando sus respectivas velas. Se acordaba tener una caja con dos llaves: una para el mayordomo y otra para diputado mayor, con la finalidad de resguardar los bienes y limosas para el culto divino, sufragio de las ánimas del purgatorio, regalo a los pobres que enfermaran y el cuidado de los padres guardianes. Por último se recordaba que los cofrades fundadores y los que entrasen quedaban sometidos al fuero y jurisdicción eclesiástica. ${ }^{74}$

En cuanto a sus finanzas, en 1665, los libros de cuentas manifiestan haber tenido de recibo "doscientos y treinta pesos y tres tomines y de gasto en cera, vino, misas y otras cosas necesarias de la dicha cofradía, doscientos y sesenta y cinco pesos y cinco tomines, con que parece excede el gasto al recibo en treinta y cinco pesos y dos tomines los cuales perdonaron a la dicha cofradía". ${ }^{75}$ En 1671 se

${ }^{73}$ Testimonio de la escritura que José Joaquín del Castillo sobre el gravamen de 100 pesos que cargo sobre su casa a réditos del $5 \%$ anualmente a favor de la capilla de la Tercera Orden de la ciudad de Tzintzuntzan, de los 100 pesos era deudor Juan Cuadrada, ya difunto y su albacea Josef Cayetano de Lezo los invirtió en beneficio de su alma. 26 de febrero de 1783, Aнсмо, Obras pías, Testamentos, caja 1,212, carp. 346, leg. 538, $1 \mathrm{f}$.

${ }^{74}$ Acta constitutiva de la cofradía de Chamacuero, 1666, AHCMO, Cofradías, Constituciones, caja 5, exp. 3, doc. 2, fs. 2. El acta constitutiva de la cofradía del mismo nombre en la ciudad de San Luis Potosí es más completa, pero muy similar. Una diferencia interesante es que se distingue la cooperación de varones y mujeres. Los primeros debían dar tres pesos y las segundas dos. Acta constitutiva de la cofradia de San Luis Potosí, San Luis Potosí, 1635, Ансмо, Cofradías, Constituciones, caja 5, exp. 1, doc. 1, fs. 9.

${ }^{75}$ AHCM, fondo Diocesano, sección Gobierno, serie Visitas, subserie Asientos, 1665, caja 56, exp. 9, fs. 53-57. 
registra que "han tenido de recibo doscientos y treinta y nueve pesos $\mathrm{y}$ siete reales y de gasto setecientos treinta y cinco tomines con que alcanzó el gasto a recibo en cuatrocientos noventa y seis reales" ${ }^{76}$ Ocho años después tenían de "recibo mil y treinta y ocho pesos y un tomín y medio y de gasto mil cuatrocientos diez y siete pesos, tomín $\mathrm{y}$ medio con que resulto alcance de trescientos y setenta y nueve pesos". 77

\section{Cofradia del Santo Entierro}

Esta cofradía ya es mencionada como una de las tres que existían en la ciudad en $1685 .{ }^{78}$ Como seńalamos, la capilla de la Soledad era la sede de la cofradía de Nuestra Señora de la Soledad, que entre 1671 y 1679 se le agregó el nombre de las Ánimas del Purgatorio, pero también albergaba a la cofradía del Santo Entierro de Cristo, la cual veneraba a una imagen de pasta de cańa que representaba a Cristo posando sin vida en una urna de carey. ${ }^{79}$ Este Cristo fue elaborado en el siglo XVI o a principios del XVII, cuando era común la manufactura de imaginería de pasta de caña, ligera para las procesiones que tenían lugar en el atrio y en el pueblo. En la descripción de 1766 se habla de esta imagen en su urna, que estaba depositada en la capilla de la Soledad. Si la imagen es anterior a la construcción de dicha capilla, su albergue original debió ser el templo parroquial y pudo pertenecer desde su origen a la cofradía del Santo Entierro.

En el edificio se encontraban también varios lienzos, entre los que figuraban uno de la Resurrección y otro del Descendimiento,

${ }^{76}$ AHCM, fondo Diocesano, sección Gobierno, serie Visitas, subserie Asientos, 1671, caja 57 , exp. 13, f. 79-81.

${ }^{77}$ AHCM, fondo Diocesano, sección Gobierno, serie Visitas, subserie Asientos, 1679, caja 56 , exp. 12 , f. 7 .

${ }^{78}$ AHCM, Mandatos, Provisiones Reales, 1685, caja 4, exp. 21, f. 76.

${ }^{79}$ Una descripción de 1908 dice lo siguiente "Llama la atención en este templo, una primorosa urna de carey armada sobre una armazón de plata y con aplicaciones del mismo metal sobre el carey en el que forman bellísimos y artísticos dibujos. Esta rica urna encierra una magnífica escultura del Santo Entierro, del tamaño natural”. J. M. de la Puente, “Tzintzuntzan”, 418. En la actualidad el Cristo sigue siendo una de las imágenes más veneradas de la ciudad. Se tiene la creencia de que aumenta de tamaño. 
ambos de dos varas. ${ }^{80}$ Es probable que también pertenecía a esta cofradía un lienzo del Descendimiento de Cristo que en el siglo xIX se encontraba en el templo de San Francisco, el cual medía 3 x 6 varas. Este último comenzó a cobrar fama desde finales del siglo xIX, pues, se difundió la idea de que había sido pintado por el artista italiano Tiziano Vecellio y que había sido un obsequio de Carlos V para Vasco de Quiroga o de Felipe II a fray Jacobo Daciano. Otros creyeron que era obra de Murillo, Ibarra, Lucas Giordano, Velázquez o el Greco. ${ }^{81}$ El médico y conocedor de arte Nicolás León, dijo haber revisado los archivos parroquiales de Tzintzuntzan (hoy desaparecidos), sin encontrar noticia de la pintura hasta el último tercio del siglo XVII, donde un inventario refería un lienzo grande de un "Santo Entierro de Cristo". Su investigación lo llevó a pensar que la obra no era del siglo XVI como se creía sino del XvII, posiblemente pintada por Baltasar de Echave y Rioja. ${ }^{82}$ En 1934, el reconocido historiador del arte Manuel Toussant opinó que era más probable que la pintura fuera de Baltazar de Echave, pero no Rioja como lo creyó

${ }^{80}$ Se sabe que en otros lugares había una relación entre las cofradías de la Soledad con la del Santo Entierro, también llamada del Descendimiento de Cristo, como en Pátzcuaro, donde se encontraba la "Cofradía del Descendimiento de Cristo Señor Nuestro, Santo Entierro y Soledad de su Santísima Madre fundada con facultad ordinaria en el convento y Santuario de Nuestra Señora de la Salud y Hospital de Santa Martha de indios de esta ciudad". Dicen Gemma Flores y Carlos Paredes que se tiene noticia de la existencia de esta cofradía en el año de 1618, aunque se le dio formalmente la categoría de cofradía hasta 1719. Laura Gemma Flores García y Carlos S. Paredes Martínez, "El cabildo, hospital y cofradía de indios de Pátzcuaro: ámbitos de poder y conflictos en el siglo XviI", en Autoridad y gobierno, 194-195. Dagmar Bechtloff por su lado, tiene como fecha de fundación de la Soledad de Nuestra Señora en 1695, y la del Santo Entierro en 1718, que se fusionaron. Bechtloff, Las cofradias en Michoacán, 101.

${ }^{81}$ También se refiere "un Descendimiento de Nuestro Señor, de medio relieve con sus dos columnas doradas, su estatua de un cuerpo mide más de una cuarta", AHCM, religiosos, franciscanos, caja 275, exp. 142, 136 fs. Inventario de la plata y de las imágenes de la capilla de la Soledad. Tzintzuntzan, 25 de noviembre de 1766 . El cuadro no es el que refiere el documento de 1766, pues, aquel medía menos de $1.70 \mathrm{~m}$, y el llamado "Tiziano" medía $4.77 \mathrm{~m}$ de ancho por $2.90 \mathrm{~m}$ de alto. Fernando Zarraga, El entierro de Cristo de Tzintzuntzan, ¿Un Greco? (México: M. Gómez, 1927), 4. Por desgracia el lienzo se destruyó en el incendio de abril de 1944.

${ }^{82}$ Nicolás León, Nota acerca de una pintura existente en el antiquísimo Convento de Franciscanos en Tzintzuntzan, atribuida al Tiziano (Impr. del Gobierno en la Escuela de Artes, 1891). 
Figura 3. Imagen del Santo Entierro que se encuentra en la capilla de Nuestra Señora de la Soledad

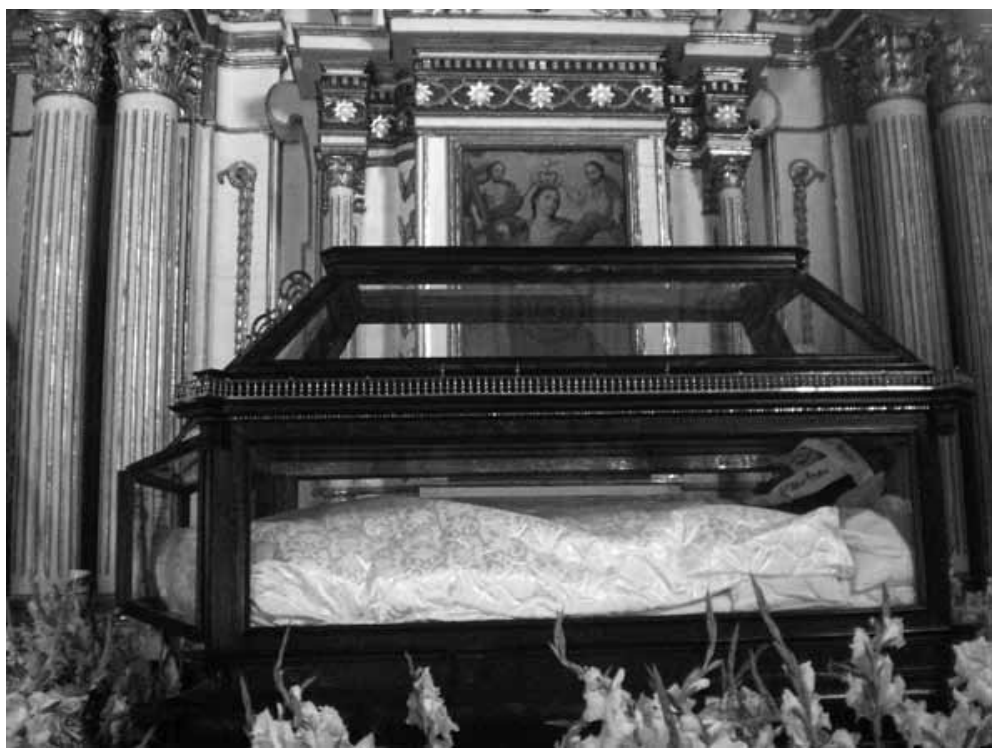

Fotografía tomada por el autor en diciembre de 2013.

León, sino Orio, por lo tanto, fue elaborada a finales del siglo Xvi o en los albores del siguiente siglo. ${ }^{83}$

Dice Bechtloff que "la cofradía del Santo Entierro se había propuesto como fin promover y divulgar la devoción en memoria de la Crucifixión de Cristo y la soledad de su santa madre" ${ }^{84}$ La conmemoración principal de esta cofradía se realizaba el Jueves Santo, cuando la imagen de Cristo, que tiene brazos articulados, se sacaba de la urna y simbólicamente se crucificaba afuera de la capilla de la Soledad en medio de las imágenes de Dimas y Gestas. El viernes siguiente, la urna del Santo Entierro era llevada en procesión por los cofrades

${ }^{83}$ El estudio fue hecho en 1934. Manuel Toussaint, Pintura colonial de México (México: Instituto de Investigaciones Estéticas, unAM, 1965). José Manuel Martínez Aguilar, El “Tiziano" de Tzintzuntzan, el lienzo que se convirtió en leyenda”, Signos Históricos XviII(36) (julio-diciembre, 2016).

${ }^{84}$ Bechtloff, Las cofradias en Michoacán, 101, 104. 
de ida y vuelta hasta la capilla de la Virgen de Guadalupe, a las afueras de la ciudad. En la procesión también participaban penitentes descalzos y casi desnudos que se flagelaban o cargaban una pesada cruz de madera, así como hombres y mujeres que acompañaban el féretro. Otra de las fiestas más importantes era el Descendimiento de la Santa Cruz, efectuada del 29 de septiembre al 2 de octubre. ${ }^{85}$

\section{Cofradía del Divinísimo Señor Sacramentado o Santísimo Sacramento}

La cofradía del Santo Sacramento o del Divinísimo fue erigida en 1712 con autoridad y licencia del señor provisor don Pedro Cienfuegos; ${ }^{86}$ fundada por un grupo de españoles encabezados por el padre fray Pedro Tovar, guardián fundador; fray Joseph Valdovinos, cura; fray Juan Antonio Arcaute, conventual; Juan Díaz Barriga, Joseph de Mier y don Millán Izquierdo, vecinos, con destino al culto y luminaria. ${ }^{87}$ Un informe aseguraba que para 1712 , la cofradía del Divinísimo era la única cofradía que se encontraba activa, aunque sabemos que la de Nuestra Señora de la Soledad, la de San Nicolás y la de la Inmaculada Concepción seguían funcionando, pero por alguna razón no son mencionadas. ${ }^{88}$

Entre las actividades de esta cofradía estaban la oración y el pago de misas. El tercer domingo de cada mes pagaban para que se ofreciera una misa cantada en honor al Santísimo; el Miércoles Santo costeaban otra a la Preciosísima Sangre de Cristo; en la domínica infraoctava del Corpus ofrecían también una misa cantada y sermón con vigilia por cada cofrade difunto y otra anual por los vivos. Como las demás cofradías, participaban en la conmemoración de la Semana Santa, principalmente, en las procesiones del Jueves Santo y Viernes Santo, en las procesiones del Domingo de Resurrección y el

${ }^{85}$ Ibid., 138.

${ }^{86}$ Brading y Mazín, eds., El gran Michoacán, 221.

${ }^{87}$ APT, libro $1^{\circ}$ de la cofradía del Santísimo Sacramento, f. 1. Relación de cofradias. Informes sobre el número y estado de las cofradias y hermandades existentes en esa provincia, AGN, Ciudad de México, ramo Cofradías y Archicofradías, vol. 18, exp. 5, fs. 207v.

${ }^{88}$ Brading y Mazín, eds., El gran Michoacán, 221. 
Domingo de infraoctava del Corpus Christi, así como en las fiestas principales del pueblo. En la procesión del Viernes Santo se sacaban en hombros a las imágenes que pertenecían a los antiguos barrios que fueron congregados a la cabecera.

De acuerdo con las constituciones de la cofradía con este nombre, en otros lugares de Michoacán, que son similares entre sí, se deduce que la de Tzintzuntzan funcionaba más o menos así: la fundación se concretaba con el acta de constituciones, aprobada por el obispo en turno, el guardián del convento y los miembros de la organización recién formada. Hechas las elecciones de los cargos, se establecía una caja en la parroquia, con velas encendidas. Se estipulaba que cada que saliera el Santísimo Sacramento del templo se repicaran las campanas hasta que éste regresara. Los cofrades y hermanos participaban en las procesiones con candelas encendidas y algunos pedían limosnas, sobre todo, los domingos y días festivos. La fiesta del Corpus se celebraba con música y se repicaban las campanas. En vísperas solemnes se cubría el Santo Sacramento y el Jueves Santo los cofrades lo velaban. Los miembros cooperaban con dos pesos de oro común y los que se sentían cerca de morir, daban el doble. Cuando fallecía un cofrade, el mayordomo y los diputados estaban obligados a pagar la misa y los gastos de entierro. Después se debían ofrecer tres misas por el alma del difunto. ${ }^{89}$

Cuando se llevó a cabo el proceso de la secularización de la doctrina y curato de Tzintzuntzan entre 1762 a 1766, la gente del lugar pidió con ahínco al obispo y al virrey que no les quitaran a los franciscanos, pero no tuvieron éxito. En 1766, cuando la secularización era inminente, se corrió la noticia de que se había aparecido el Divinísimo Señor Sacramentado en forma de custodia sobre el sagrario que se encontraba en el templo de San Francisco. ${ }^{90}$ El supuesto milagro llegó a oídos del obispo de Michoacán, pero esto no tuvo incidencia en la disposición de recoger la doctrina a los franciscanos.

${ }^{89}$ Constituciones de la cofradía del Santísimo Sacramento de Irapuato, Irapuato, 1690, Ансмо, Cofradías, Constituciones, caja 5, exp. 8, doc. 1, f. 3.

${ }^{90}$ Secularización de la doctrina y curato de Tzintzuntzan, 1762-1767, АНСM, fondo Diocesano, sección Gobierno, serie Religiosos, subserie Franciscanos, caja 275, exp. 142, $136 \mathrm{fs}$. 
Al principio, la del Divinísimo únicamente se sostenía de las limosnas de los cofrades, pero con el tiempo adquirieron un rancho, ganado y otros capitales. Según el inventario de los bienes de esta cofradía al momento de la secularización de la parroquia franciscana, ésta contaba con caballerías, tierras, 25 vacas, 3 becerros, 3 becerras, caballo, 2 yeguas y una troje para almacenar el trigo. También tenían en su poder algunas alhajas, platos de plata, una imagen de Cristo crucificado, una imagen de Nuestra Señora de Dolores, así como un libro que iniciaba en 1712, con 67 fojas. ${ }^{91} \mathrm{~A}$ finales del siguiente siglo (1791) sus fondos consistían en "1000 pesos sobrantes de los cornadillos con que se compró una huerta de tierras que, arrendadas, producen los cincuenta pesos correspondientes; y en otros 200 pesos impuestos a réditos y donados por un devoto que se sacan a la segunda clase y los 1000 a la primera", gastaba 137 pesos anuales en misas, sermones y sacristán, además de dos pesos por la misa que se decía cuando moría algún cofrade. ${ }^{92}$

Se invierten dichos réditos en una misa cantada el tercer domingo de cada mes; misa y sermón el miércoles santo a la Preciosísima Sangre de Cristo; misa y sermón en la domínica infraoctava del Corpus; una misa cantada con vigilia por cada cofrade difunto y otra anual por todos, cera y demás necesario para el monumento y los viáticos a que no alcanza.

Las últimas noticias que se tienen en relación con esta cofradía son dos. La primera de 1779 , atestigua que cuatro de sus miembros: don Felipe Âlvarez, don Juan Cuadradas, don Joaquín del Castillo y don Laurencio Lubiano aportaron siete pesos y medio, cada uno, para mandar fabricar un cancel del templo que costó 32 pesos rea-

${ }^{91}$ Inventario de los bienes y alhajas de la cofradía del Señor Sacramentado. Tzintzuntzan, a 25 de noviembre de 1766, AHCMO, Religiosos, Franciscanos, caja 275, exp. 142. "Noticia del número de cofradías o hermandades que hay en esta provincia de Valladolid, época de su fundación y licencia, sus fondos, destino con que se exigieron, demandas que circulan, con que permiso y su inversión". Noviembre 29 de 1792, dentro del expediente titulado Relación de cofradias. Informes sobre el número y estado de las cofradias y hermandades existentes en esa provincia, AGN, ramo cofradías y archicofradías, vol. 18, exp. 5, f. 207v.

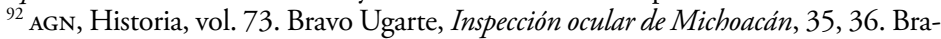
ding y Mazín, eds., El gran Michoacán, 221. 
Figura 4. Vestigios de la capilla de la Tercera Orden

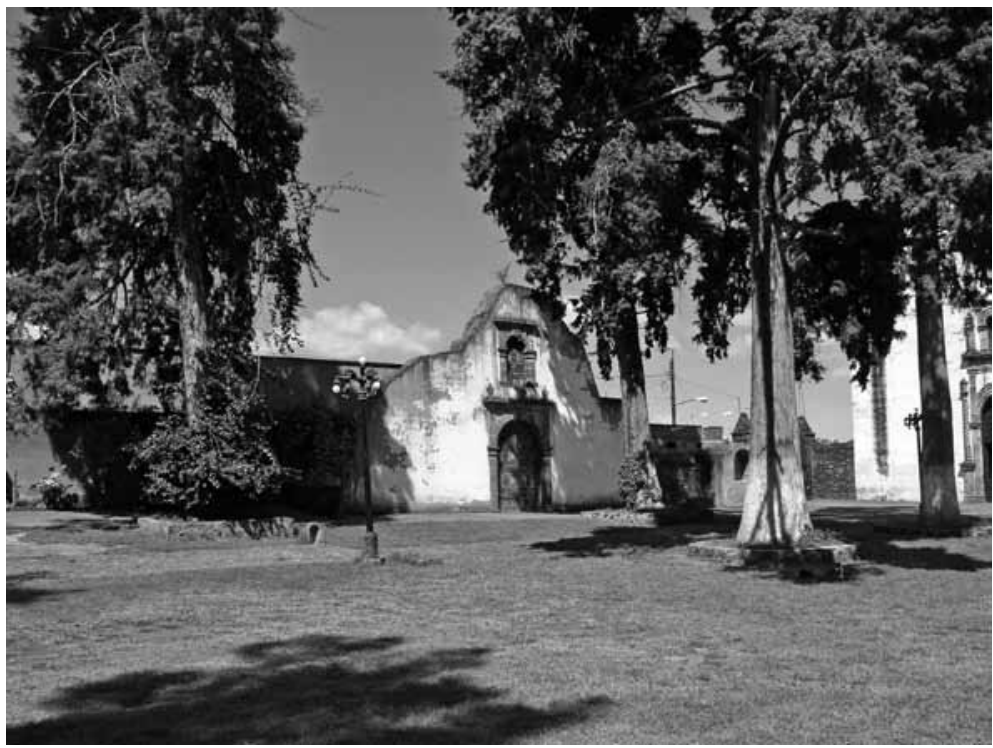

Fotografía tomada por el autor en diciembre de 2003.

les; el resto de lo que costaba dicho cancel los aportó el cura beneficiado don Manuel de Anzo. La idea de este elemento era básicamente bloquear el exceso de aire que entraba al templo y que consumía rápidamente las costosas velas. ${ }^{93}$ La segunda noticia es de 1795, cuando se asienta que se presentaron dos libros de las cuentas de la cofradía, aunque no dan mayor información al respecto. Lo que sí se afirma es que, para entonces, ésta era la única que existía en el curato de Tzintzuntzan, aparte de la del hospital de la cabecera y

${ }^{93}$ José de Lezo da razón de los costos del cancel que está en la puerta del costado de la Parroquia de esta ciudad y que se terminó el día veintiuno de enero de mil setecientos setenta y nueve, firmas de Felipe Álvarez, Manuel de Anzo et al., CEHM, CARSo, fondo XXVIII, leg. 214, carp. 7, doc. 1, f. 1 . No todas las capellanías y obras pías se hacían a favor de las cofradías, el templo de San Francisco y el mismo convento, también eran favorecidos por los vecinos. Un inventario, por ejemplo, registró dos capellanías, dos escrituras, la donación de una casa al convento por parte de Juan Rendón, en 1754, entre otras donaciones. Inventario de las escrituras de capellanias, dotaciones, plata y ornamentos del templo parroquial de Tzintzuntzan. 23 de noviembre de 1766, Ансмо, Religiosos, Franciscanos, caja 275, exp. 142, 136 fs. 
los de Cocupao e Ihuatzio, aunque éstos "eran manejados por los gobernadores", y no se tenía conocimiento de sus bienes. ${ }^{94}$

\section{Cofradia de la Tercera Orden de San Francisco}

La cofradía de la Tercera Orden o del Tercer Orden, fue fundada en 1723 por Joseph de Leso, bajo la patente de fray Juan de Guevara, con el fin de permitir que hombres y mujeres que no tenían tiempo ni inclinación para convertirse en frailes o monjas pudieran entrar activamente en la vida religiosa de la orden franciscana. ${ }^{95}$ Dos años después de su fundación, el ministro provincial fray José Díaz de Prado ratificó el permiso para que los miembros de esta cofradía llevaran a cabo sus reuniones en la sala capitular del convento sin que el guardián del mismo ni nadie pudiera impedírselos, además de establecer los estipendios que sus miembros deberían pagar por misas y fiestas. ${ }^{96}$

Durante unos cuarenta años tuvieron sus reuniones en la sala capitular del convento de San Francisco hasta que terminaron su capilla propia, al parecer, unos meses o ańos antes de 1766, de

${ }^{94}$ Informe presentado por el cura de Tzintzuntzan sobre su curato: pueblos que administra, distancias, capellanías, obras pias y número de feligreses, 4 de mayo de 1795, АНСм, fondo Diocesano, sección Gobierno, serie Informes, 0215, caja 511, exp. 109, fs. 43.

${ }^{95}$ La cofradía se formó con hombres y mujeres que tenían los siguientes cargos: hermano mayor (Mateo López), hermana mayor (Manuel Díaz Barriga), maestro de novicios, maestra de novicios, mandatarios y mandatarias, celadores y celadoras, campanero, secretario y enfermera. Libro en que se asientan los hermanos que han tomado el hábito de la Tercera Orden de N. P. S. Francisco fundada en la ciudad de Tzintzuntzan con la autoridad necesaria de N. M. R. P. fray Juan de Guevara Ministro Provincial de esta Sta. Provincia de San Pedro y San Pablo de Michoacán..., 25 de agosto de 1725, APT, libro 1º de la Cofradía de la Tercera Orden, f. 1 . La fecha de 1725 debe ser incorrecta porque fray Juan de Guevara había sido Provincial de 1721 a 1723 o 24, además de que en febrero de 1725 el provincial fray José Díaz de Prado declaró que hacía poco tiempo que se había fundado dicha cofradía y que se habían perdido los papeles de erección. Probablemente la fecha de agosto de 1725 fue en la que se inició el libro.

${ }^{96}$ Fray José Díaz de Prado concede licencia para que, en la Iglesia del Convento, puedan tener sus ejercicios según el tenor y forma que ordenan las constituciones y asigna el estipendio que deben pagar por las misas y fiestas que tienen obligación de hacer en el año. Juan de Guevara. 21 de febrero de 1725. CEHM CARSo, fondo XXVIII, leg. 212, carp. 7, doc. 1, f. 2 . Según el libro de cuentas de la Orden, en 1754 tuvieron de recibo la cantidad de 171 pesos y 21 reales; de gato: 294 pesos y 4 reales. APT, Libro $1^{\circ}$ de la cofradía de la Tercera Orden, f. 40. 
acuerdo a una descripción de este año que deja ver que las paredes y el altar eran nuevos.

y también el cañón de la iglesia es de treinta varas de longitud, diez de amplitud con crucero en el tramo mayor, dos tramos y medio encuartonada el tegumento $[s i c]$ de artesón, las paredes nuevas de adobe con coro correspondiente al cuerpo de la iglesia, púlpito de madera de pino, con su tornavoz y ambos pintados y muy decente [...] El tegumento superior de tejamanil y al lado diestro una torrecita de adobe que tiene dos cuerpos algo maltratada tres campanas [...] sacristía de nueve varas de largo y cuatro de ancho $[\ldots]$ y también un altar mayor que tendrá siete u ocho varas de alto de dos cuerpos y medio: en el primero tiene en medio una Seńora de Dolores de bulto de tres cuartas de alto dorada, en una repisa de madera [pintada], con manto y túnica de capichola [...] así mismo al pie de dicha Señora, hay una imagen de San Francisco de dos tercias de alto, todo de madera dorada y pintado su manto correspondiente de estameńa [...] y también dicho altar es todo de madera de pino, a excepción de los pilares que son de tzirimu, todo de media talla nuevo, y nada dorado. ${ }^{97}$

Como nos habla de una torre algo maltratada no se sabe si esta tenía más antigüedad que la nave, aunque no sería raro que antes de esta capilla, hubiese existido otra más sencilla en su lugar, como sucedió con la de la Soledad. De cualquier manera su origen fue después de 1722 o 1723, por lo que llama la atención que en el mapa que presenta Beaumont en su Crónica ya aparezca el edificio. ${ }^{98}$ Si es verdad que el padre la copió de una pintura que habían hecho los indios de Tzintzuntzan, o la original no era tan antigua como se creía o la reproducción que hizo el padre franciscano le agregó numerosos elementos que existían en el tiempo que él vivió. Para 1792, la capilla de la Tercera Orden era: "de adobe con la torre adjunta, tiene entablados el pavimento y cielo, su crucero y cuatro altares con otros tantos retablos de mala figura y pésima talla" ${ }^{99}$

${ }^{77}$ Secularización de la doctrina y curato de Tzintzuntzan, 1762-1767, АHCM, fondo Diocesano, sección Gobierno, serie Religiosos, subserie Franciscanos, caja 275, exp. 142, f. 130.

${ }^{98}$ Beaumont, Crónica de Michoacán.

${ }^{99}$ AGN, Historia, vol. 73. José Bravo Ugarte, Inspección ocular de Michoacán, 35. Lo 
En cuanto a los bienes de esta cofradía, en la información para la secularización del curato y doctrina, sólo se menciona una lámpara, dos coronas, alhajas, una custodia, un cáliz, algunas casullas y otros objetos, como lienzos y mobiliario. ${ }^{100}$ Dos inventarios más, uno de finales del siglo XviII y otro de principios del XIX, nos describen brevemente las alhajas y los ornamentos de las imágenes de san Francisco, santa Gertrudis, el Señor de la Buena Muerte, Nuestra Señora de Dolores, Señor San José, Nuestra Señora del Pilar, Señor de la Columna, además de lienzos, muebles y otros objetos para el culto, que se tenían en la capilla. ${ }^{101}$

La imagen de su veneración principal era san Francisco, por lo que la fiesta la celebraban el 4 de octubre, pero también era muy venerada la Señora de Dolores. En la fiesta de San Francisco se oficiaba una misa solemne en honor al santo patrono; por la tarde se sacaba la imagen de San Francisco por las principales calles de la ciudad; el mismo día se realizaba gran verbena en el pueblo, donde se "jugaba con los toros", se hacían peleas de gallos y juegos de cartas, donde no faltaban las bebidas embriagantes aunque estuvieran prohibidas por las autoridades. ${ }^{102}$ En la procesión del silencio, es probable que como se hace en la actualidad, los miembros de esta asociación religiosa caminaran por las calles descalzos a manera de penitencia con una capucha en la cabeza. Es posible que sus miembros se flagelaran públicamente, práctica común en todos los territorios españoles y prohibida por Carlos III en 1767.

que hace un año atrás se podía ver era sólo una pared incompleta del frontispicio de la capilla, con sus vanos de puerta y ventana, que ahora ha sido "reconstruida". Todavía en una fotografía de la década de 1920, que tengo en mi mano, se podía ver su fachada y torre completa.

${ }^{100}$ Secularización de la doctrina y curato de Tzintzuntzan, 1762-1767, AHCM, fondo Diocesano, sección Gobierno, serie Religiosos, subserie Franciscanos, caja 275, exp. 142, f. 130.

${ }^{101}$ Inventario de las alhajas que hay en este venerable Orden Tercero que entrega el hermano coadjuntor D. Ventura Morales al ministro hermano mayor D. José Maria Fuentes es lo siguiente. 18 de febrero de 1790, CEHM CARso, fondo XXVIII, leg. 217, carp. 7, doc. 1, f. 2. Véanse anexos. 1. Inventario de las alhajas que hay en el orden tercero. José María Fuentes, Ramón Urbina et al. 15 de julio de 1822, CEHM, fondo xxvIII, leg. 219, carp. 7, doc. 1, f. 2, Tzintzuntzan.

${ }^{102}$ AHCP, caja 19 B, folder 4, 52 fs. Problema que tienen los naturales de Tzintzuntzan con el convento de San Agustín de Pátzcuaro por un sitio de tierra llamado San Lorenzo, 1710-1719. 
Los cofrades de la Tercera Orden eran españoles de prestigio social y solvencia económica, quienes estaban comprometidos con su cofradía, dejando capellanías y obras pías a favor de la misma y del templo parroquial. ${ }^{103}$ Tras la secularización de la parroquia de San Francisco y el convento de Tzintzuntzan, los terciarios se negaban a entregar las llaves de la capilla, ${ }^{104}$ incluso aún después de que oficialmente se concretó la secularización, los cofrades encabezados por don Juan Cuadradas se reunían con el último guardián franciscano de Tzintzuntzan, fray Miguel Valverde, en casa de un capitán de nombre Gaspar Sanabria. Después de que se vieron obligados a entregar la capilla al cura secular, la cofradía siguió en función. El mismo Juan Cuadradas llegó a tener el cargo de hermano mayor de la cofradía de la Tercera Orden en 1776, mientras que un personaje interesante, Cristoval Tejada ( $(s i c)$, era el tesorero. ${ }^{105}$ Después de esto, algunos de sus miembros pensaban que se extinguiría la cofradía, por lo que estipulaban que en caso de que así fuera, sus obras pías pasaran a la capilla de los hermanos terciarios de Pátzcuaro. ${ }^{106}$ No desapareció inmediatamente, pues, el libro de la cofradía termina hasta $1824 .{ }^{107}$

${ }^{103}$ Tzintzuntzan, 26 de febrero de 1783. Testimonio de la escritura que José Joaquín del Castillo sobre el gravamen de 100 pesos que cargo sobre su casa a réditos del $5 \%$ anualmente a favor de la capilla de la Tercera Orden de la ciudad de Tzintzuntzan, de los 100 pesos era deudor Juan Cuadrada, ya difunto y su albacea Josef Cayetano de Lezo los invirtió en beneficio de su alma. 26 de febrero de 1783, AHCMO, Obras pías, Testamentos, caja 1,212, carp. 346, leg. 538, $1 \mathrm{f}$.

${ }^{104}$ Secularización de la doctrina y curato de Tzintzuntzan, 1762-1767, AHCM, fondo Diocesano, sección Gobierno, serie Religiosos, subserie Franciscanos, caja 275, exp. 142, f. 130.

${ }^{105}$ Cristoval Tejada había tenido los cargos principales de la cofradía del Divinísimo Señor Sacramentado, gastando de su propio bolsillo para las funciones de la cofradía. También fue cuatro veces hermano mayor de los terciarios. Se sabe que era caritativo y que en una ocasión dio socorro a cuatro nińas, becándolas para que estudiaran en un colegio seminario. APT, libro $1^{\circ}$ de la Cofradía de la Tercera Orden, f. 18 v. Memoria de Christoval de Tejeda uno de los vecinos de esta ciudad, 1785, fs. 24 y 27. APT, libro 7 de informaciones matrimoniales.

106 Testimonio de la escritura que otorgó Don José Joachin del Castillo sobre el gravamen de cien pesos que cargó en su casa a réditos de cinco por ciento anualmente a favor de la Tercera Orden de la ciudad de Tzintzuntzan con las condiciones que adentro se expresan, 1 de octubre de 1782, АНСм, fondo Diocesano, sección Justicia, serie Testamentos, Capellanías, Obras pías, subserie Testamentos, caja 1212, carp. 346, leg. 538, f.

${ }^{107}$ APT, libro $1^{\circ}$ de la Cofradía de la Tercera Orden, f. 40. 


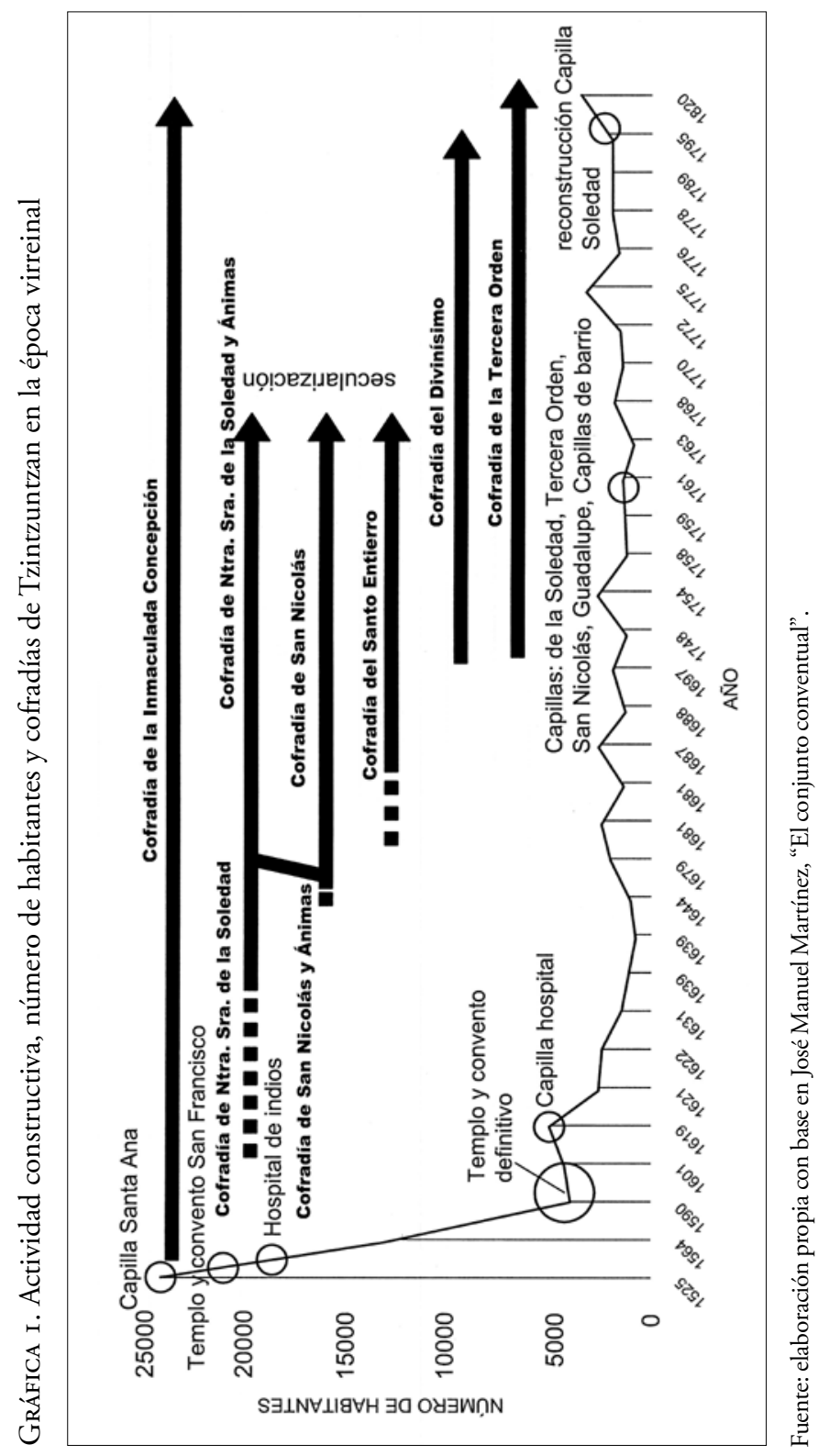




\section{CONCLUSIÓN}

En Tzintzuntzan, como en otros lugares de la Nueva España, las cofradías tuvieron un papel primordial en la época virreinal, ya que permitieron la colaboración del pueblo para fines comunes como la atención a los enfermos socorro a las viudas y desamparados; educación básica; también permitieron, por medio de limosnas y la administración de tierras de cultivo y ganado, obtener ingresos para su funcionamiento, el hospital de indios y los gastos parroquiales. En otras palabras, fueron un medio para alentar la caridad; el sentido de pertenencía a un grupo; redimir culpas; obtener un prestigio social en el pueblo; costear fiestas; salarios de los religiosos y obras materiales.

Al menos desde mediados del siglo xvi, la cofradía de la Inmaculada Concepción fue fundada para administrar el hospital de indios. A finales del mismo siglo, fray Pedro de Pila gestionó la construcción de un nuevo "suntuoso" convento y templo en el lugar, además de fundar un coro y una cofradía, probablemente la de Nuestra Señora de la Soledad. La primera obra material de importancia del siglo XVII fue la reconstrucción de la capilla del hospital, cuya fecha de 1619 aún se puede ver en la portada. Sin embargo, la situación de Tzintzuntzan comenzó a ponerse difícil debido a que su noviciado pasó a la ciudad de Valladolid y a que dejó de ser casa capitular, teniendo con ello menor apoyo de la provincia. Los gastos para el sostenimiento material y espiritual de la parroquia siguieron siendo los mismos, pero para solventarlos se habían hecho fundamentales las contribuciones del pueblo a través de los servicios religiosos, la mano de obra para las reparaciones de los edificios y lo poco que podían aportar las cofradías. En tiempo de decadencia se conservó la cofradía de la Concepción y se fundaron la de San Nicolás Tolentino y la del Santo Entierro, las que decían tener más gasto que recibo. ${ }^{108} \mathrm{El}$ hecho es que ni los recursos económicos ni la mano de obra eran suficientes para sostener de pie el convento y el templo que continuamente sufría deterioros en

${ }^{108}$ Otras dos cofradías son mencionadas como "de Tzintzuntzan" en una minuta de hierros de finales del siglo xvir: la de San Gerónimo y la del Santo Niño. La primera tenía por mayordomo a Lázaro Morales y la segunda a Lucas Gaspar. No se ha localizado al momento ningún otro documento que las vuelva a mencionar. 
las cubiertas y muros. Por ello, las autoridades locales y la república de indios solicitaron constantemente apoyo al virrey, en el sentido de que reservara a los indios que eran enviados a las minas de Guanajuato para que colaboraran en la reconstrucción de sus edificios. ${ }^{109}$

Para mediados del siglo xvini, la cofradía del hospital, la de San Nicolás Tolentino y la de Nuestra Seńora de la Soledad seguían en funcionamiento; además se había fundado la del Divinísimo y la de la Tercera Orden, ambas por grupos de españoles. Las obras materiales de esta centuria nos sugieren que la situación económica del pueblo había mejorado, o al menos la de los españoles miembros de las cofradías que poseían importantes haciendas en la región. Las tres contribuyeron al sostenimiento de la parroquia, así como al mantenimiento y ornato de los edificios, la integración de retablos, pintura mural, canceles, lienzos, imágenes de pasta de cańa y madera, etcétera, además, adquirieron objetos costosos para el culto divino y para el adorno de sus imágenes, como lo revelan los inventarios de sus bienes. Como muestra del poder adquisitivo de las organizaciones religiosas, a mediados de este siglo la cofradía de la Soledad construyó su propia capilla. Los miembros de la Tercera Orden no se quedaron atrás y levantaron la suya. Después de la secularización, las únicas cofradías que sobrevivieron fueron la de la Tercera Orden, la Soledad, y la Concepción, aunque esta última muy disminuida, en comparación con lo que había sido. Por su parte, los miembros de la Soledad echaron abajo su antigua capilla y construyeron a finales de este siglo y principios del XIX, con ayuda del cura Manuel Nicolás de Leso y José Francisco Velasco una de mayores

${ }^{109}$ Su Excelencia reserva por dos años a doce indios de lo que tienen obligación de acudir al repartimiento para que acudan al reparo de su iglesia y convento de Tzintzuntzan, 1621, AGN, Instituciones Coloniales, Real Audiencia, indios, contenedor 06, vol. 9, exp. 308, fs. 150v151v. El gobernador y naturales de dicho pueblo, sobre reparación de un templo, Tzintzuntzan, 1639, AGN, Instituciones Coloniales, Real Audiencia, Tierras, vol. 97, exp. 4, 9 fs. Se ordena al Alcalde mayor de la Provincia de Michoacán vaya con el Ministro de doctrina de Tzintzuntzan y dos alarifes a ver qué reparos necesita la iglesia, el tiempo que durará la obra y cuánto costará, a fin de resolverlos convenientemente la petición de reserva a los naturales del pago de tributos, 1688, AGN, Indios, vol. 30, exp. 202, fs. $191 \mathrm{f}-191$. Se concede a los naturales de Tzintzuntzan, Provincia de Michoacán, no pagar la cuarta parte de lo que importa el total de tributos en ocho años, para que puedan reedificar su iglesia, 1691, AGN, Instituciones Coloniales, Real Audiencia, Indios (058), contenedor 17, vol. 30, exp. 434. 
dimensiones, que competía con el templo parroquial, que se conserva hasta la actualidad.

Las obras materiales del pueblo pueden reflejar los periodos de crisis o bonanza económica de sus habitantes, pero también la iniciativa de la sociedad y las cofradías para mantenerlas y mejorarlas. En este estudio se puede apreciar que las obras materiales más importantes de Tzintzuntzan se llevaron a cabo en la primera mitad del siglo XVI, a finales del mismo y a principios del siguiente siglo con la reconstrucción de la capilla del hospital. Después se observa un periodo amplio de casi siglo y medio donde no se tiene evidencia de actividad constructiva, hasta mediados del siglo XviII, luego de que el gobernador Ramón Flamenco de la Peña apoyó la construcción de las casas reales; la reparación del templo y convento; erección de una torre de calicanto junto al templo; el tejado de la capilla mayor; la construcción de la capilla de Nuestra Señora de Guadalupe a las afueras de la ciudad; la ampliación del hospital de Nuestra Señora de la Concepción; y la reconstrucción de todas las capillas de la ciudad, en colaboración con las cofradías. ${ }^{110}$

Coincidiendo con la secularización del curato y doctrina del lugar, el visitador José de Gálvez presentó una cédula emitida por el rey, donde se ordenaba someter las finanzas de los pueblos bajo el control del gobierno real y limitar los gastos religiosos de los cabildos, como los que tenían que ver con las celebraciones religiosas provenientes de las cajas comunales. El dinero sobrante se enviaría a las cajas reales para ser utilizado como ayuda a los indios en tiempos de epidemias y hambrunas, aunque en la realidad muy poco del ahorro fue retribuido a los mismos ya que los recursos eran enviados a Espańa, principalmente, para financiar sus guerras contra Inglaterra y Francia.

Aunque no es tema de este trabajo, se puede observar que si bien las cofradías desaparecieron, los cargos y obligaciones que desempeñaban, al igual que las fiestas y conmemoraciones del periodo virreinal, se asemejan a los cargos que realizan actualmente los cargueros de la Soledad y a las prácticas simbólico-religiosas actuales de la gente de Tzintzuntzan.

${ }^{110}$ Paniagua Aguilar, "De la privilegiada y leal”, 83-85. 


\section{ARCHIVOS}

AHCMo (Archivo Histórico Casa de Morelos)

AGN (Archivo General de la Nación)

CEHM (Centro de Estudios de Historia de México)

APT (Archivo Parroquial de Tzintzuntzan)

\section{REFERENCIAS BIBLIOGRÁFICAS}

Beaumont, Pablo. Crónica de Michoacán. 3 Vols. Morelia: Balsal, 1985.

Bechtloff, Dagmar. "La formación de una sociedad intercultural: las cofradías en el Michoacán colonial”. Historia Mexicana 43(2) (170) (octubre-diciembre 1993).

Las cofradias en Michoacán durante la época de la Colonia. La religión y su relación política y económica en una sociedad intercultural. Zinacantepec: El Colegio de Michoacán, El Colegio Mexiquense, 1996.

Brading, David A. y Óscar Mazín, eds. El gran Michoacán en 1791. Sociedad e ingreso eclesiástico en una Diócesis novohispana. México: El Colegio de Michoacán, El Colegio de San Luis, 2009.

Bravo Ugarte, José. Introducción y notas. Inspección ocular de Michoacán. México: Jus, 1960.

Carrillo Cázares, Alberto. Michoacán en el otoño del siglo XVII. Zamora: El Colegio de Michoacán, Gobierno del Estado de Michoacán, 1993.

Castro Gutiérrez, Felipe. Los tarascos y el imperio español, 16001740. México: UNAM, UMSNH, 2004.

Enkerlin Pauwels, Louise M. "El cabildo indígena de Pátzcuaro: un espacio de poder en decadencia durante la primera mitad del siglo XviII". En Autoridad y gobierno indigena en Michoacán, coord. Carlos S. Paredes Martínez y Marta Terán. México: El Colegio de Michoacán, Ciesas, INAH, UMSNH, 2003.

EsCandón, Patricia. "Tancítaro y la tierra caliente bajo la administración franciscana, 1552-1636”. Relaciones Estudios de Historia y Sociedad Xxvi(103) (verano 2005). 
Espinosa, Isidro Félix de. Crónica de la provincia franciscana de los santos apóstoles San Pedro y San Pablo de Michoacán. Apuntamientos bibliográficos de Nicolás León. Morelia: Instituto de Investigaciones Históricas, UMSNH, Morevallado, 2003.

Flores García, Laura Gemma y Carlos Paredes Martínez. "El cabildo, hospital y cofradías de indios en Pátzcuaro”. En Autoridad y gobierno indígena en Michoacán, coord. Carlos S. Paredes Martínez y Marta Terán. México: El Colegio de Michoacán, Ciesas, INAH, UMSNH, 2003.

Foster, George M. Los hijos del imperio, la gente de Tzintzuntzan. Zamora: El Colegio de Michoacán, 2000.

GutiÉrRez Equinua, Ángel. "Los hospitales de la Sierra Tarasca en el siglo XvII”. Tesis de Maestría en Arquitectura, Investigación y Restauración de Sitios y Monumentos, UMSNH, 2007.

Hernández TéLlez, Mahler. El convento de Nuestra Señora de la Asunción de Erongarícuaro 1547-1761. Tesis de Maestría en Historia, Instituto de Investigaciones Históricas, UMSNH, 2011.

López Lara, Ramón. El obispado de Michoacán en el siglo XVII. Morelia: Fimax, 1973.

López Sarrelangue, Delfina Esmeralda. La nobleza indígena de Pátzcuaro en la época virreinal. México: Instituto de Investigaciones Históricas, UnAM, 1965.

Martínez Aguilar, José Manuel. "El conjunto conventual de San Francisco Tzintzuntzan en la época virreinal, 1525-1766”. Tesis de Doctorado en Historia, Instituto de Investigaciones Históricas, UMSNH, 2015.

. Fray Pedro de Pila. El protector de Tzintzuntzan, Editorial Académica Española, 2015.

. "Fray Pedro de Pila y su obra en Tzintzuntzan". Anuario de Historia de la Iglesia (24) (2015): 383-403.

" "El Tiziano de Tzintzuntzan, el lienzo que se convirtió en leyenda”. Signos Históricos XVIII(36) (julio-diciembre, 2016).

Mazín, Óscar. El cabildo catedral de Valladolid de Michoacán. Zamora: El Colegio de Michoacán, 1996.

Paniagua Aguilar, Nicolás. "La república de indios de Tzintzuntzan. 1540-1689”. Tesis de Licenciatura en Historia, UMSNH, 2011. 
- "De la privilegiada y leal ciudad de indios al ayuntamiento constitucional de Tzintzuntzan, 1718-1826". Tesis de Maestría en Historia, Instituto de Investigaciones Históricas, UMSNH, 2015.

Paredes Martínez, Carlos Salvador, dirección general. Arquitectura y espacio social en poblaciones purépechas en la época colonial. Morelia: Ciesas, uMSNH, Universidad de Keio, 1998.

Phillips, Richard E. "La participación de los indígenas en las procesiones por los claustros del siglo Xvi en México". Relaciones Estudios de Historia y Sociedad xx(78) (primavera 1999).

Puente, José M. de la. "Tzintzuntzan, de mis notas de viajes". Revista de la Sociedad Cientifica "Antonio Alzate", vol. 27 (1 de junio de 1908).

Quiroga, Vasco de. Reglas y ordenanzas para el Gobierno de los Hospitales de Santa Fe de México y Michoacán, Dispuestas por su fundador el Rmo. Y Venerable Don Vasco de Quiroga, Primer Obispo de Michoacán. México: s. e., 1940.

Ramírez Romero, Esperanza. Catálogo de monumentos históricos de la Región Lacustre de Pátzcuaro. Tomo II. Morelia: UMsnh, Gobierno del Estado de Michoacán, 1990.

Rea, Alonso de la. Crónica de la orden de Nuestro Seráfico Padre San Francisco Provincia de San Pedro y San Pablo de Michoacán en la Nueva España. México: La Voz de México, 1982.

Ricard, Robert. La conquista espiritual de México. México: Fondo de Cultura Económica, 1992.

Ruiz Guadalajara, Juan Carlos. Documentos para la historia del obispado de Michoacán. Tomo I. México: Frente de Afirmación Hispanista, Fundación Cultural Dr. Enrique Arreguín Vélez, 1993.

Sepúlveda y Herrera, María Teresa. Los cargos políticos y religiosos en la región del lago de Pátzcuaro. Colección científica. Núm. 9, México: INAH, 1974.

Sierra Paniagua, H. Cecilia. "La cofradía del pueblo del Señor de San Juan Pungarabato". Relaciones Estudios de Historia y Sociedad XXXvi(144) (otońo 2015), 156.

TERÁN, Marta. "Políticas contra las fiestas pueblerinas michoacanas durante la época borbónica”. En Historia y sociedad. Ensayos del Seminario de Historia Colonial de Michoacán, coord. Carlos S. 
Paredes Martínez. México: Instituto de Investigaciones Históricas, UMSNH, 1997.

TorRes Vega, José Martín. "La incidencia de la orden dominica de mujeres en el espacio urbano-arquitectónico de Pátzcuaro y el obispado de Michoacán, 1747-1867”. Tesis de Doctorado en Arquitectura, Universidad Autónoma de Aguascalientes, 2013.

Toussaint, Manuel. Pintura colonial de México. México: Instituto de Investigaciones Estéticas, UNAM, 1965.

Warren, Benedict. Vasco de Quiroga y sus Pueblos Hospitales de Santa Fe. México: Ediciones Hidalgo, UMSNH, 1997.

. Michoacán en la década de 1580. Morelia: Instituto de Investigaciones Históricas, UMSNH, 2000.

Warren, Benedict y Sara SÁnchez del Olmo. Las guatáperas. México: Rotodiseño y Color, 2007.

Zarraga, Fernando. El entierro de Cristo de Tzintzuntzan, ¿Un Greco? México: M. Gómez, 1927. 